\title{
Reanalysis of long-term series of glaciological and geodetic mass balance for 10 Norwegian glaciers
}

\author{
Liss M. Andreassen, Hallgeir Elvehøy, Bjarne Kjøllmoen, and Rune V. Engeset \\ Section for Glaciers, Ice and Snow, the Norwegian Water Resources and Energy Directorate (NVE), Oslo, Norway \\ Correspondence to: Liss M. Andreassen (lma@nve.no)
}

Received: 3 November 2015 - Published in The Cryosphere Discuss.: 26 November 2015

Revised: 15 February 2016 - Accepted: 18 February 2016 - Published: 8 March 2016

\begin{abstract}
Glaciological and geodetic methods provide independent observations of glacier mass balance. The glaciological method measures the surface mass balance, on a seasonal or annual basis, whereas the geodetic method measures surface, internal, and basal mass balances, over a period of years or decades. In this paper, we reanalyse the 10 glaciers with long-term mass-balance series in Norway. The reanalysis includes (i) homogenisation of both glaciological and geodetic observation series, (ii) uncertainty assessment, (iii) estimates of generic differences including estimates of internal and basal melt, (iv) validation, and, if needed, (v) calibration of mass-balance series. This study comprises an extensive set of data (484 mass-balance years, 34 geodetic surveys, and large volumes of supporting data, such as metadata and field notes).

In total, 21 periods of data were compared and the results show discrepancies between the glaciological and geodetic methods for some glaciers, which are attributed in part to internal and basal ablation and in part to inhomogeneity in the data processing. Deviations were smaller than $0.2 \mathrm{~m}$ w.e. $\mathrm{a}^{-1}$ for 12 out of 21 periods. Calibration was applied to 7 out of 21 periods, as the deviations were larger than the uncertainty.

The reanalysed glaciological series shows a more consistent signal of glacier change over the period of observations than previously reported: six glaciers had a significant mass loss (14-22 $\mathrm{m}$ w.e.) and four glaciers were nearly in balance. All glaciers have lost mass after the year 2000 .

More research is needed on the sources of uncertainty to reduce uncertainties and adjust the observation programmes accordingly. The study confirms the value of carrying out independent high-quality geodetic surveys to check and correct field observations.
\end{abstract}

\section{Introduction}

Glacier mass-balance observations are important for studies of climate change, water resources, and sea level rise (e.g. IPCC, 2013). Mass balance is the change in mass of a glacier over a stated span of time (Cogley et al., 2011). The mass balance is the sum of surface, internal, and basal mass-balance components. In situ observations of glacier surface mass balance are termed the glaciological method (the terms direct, traditional, or conventional method are also used in the literature), where mass balance is measured at point locations and data are interpolated over the entire glacier surface to obtain glacier-wide averages. Surface mass balance is the sum of surface accumulation and surface ablation and includes loss due to calving. Mass balance can also be assessed indirectly by the geodetic method (also called cartographic) where the cumulative mass balance for a period is calculated by differencing digital terrain models (DTMs) and converting the volume change to mass using a density conversion. Whereas the glaciological method measures the surface mass balance, the geodetic method measures the sum of surface, internal, and basal mass balances. For a direct comparison of glaciological and geodetic balances methodological differences, such as differences in survey dates (account for ablation or accumulation between the survey dates) and surveyed areas (using the same area and ice divides in both methods) must be considered. In addition, effects of changes in density profiles between the geodetic surveys must be accounted for. Moreover, recent studies have shown that internal and basal melt may be substantial for temperate glaciers, in particular for maritime high-precipitation glaciers that span wide elevation ranges (Alexander et al., 2011, 2013; Oerlemans, 2013).

A comparison of glaciological and geodetic data has revealed both discrepancies and agreements (Cogley, 2009). 
Several studies on homogenisation of mass-balance records and uncertainty have been carried out recently (e.g. Thibert et al., 2008; Fischer, 2010; Zemp et al., 2010; Nuth and Kääb, 2011; Huss et al., 2015). A joint paper from the workshop on "Measurement and Uncertainty Assessment of Glacier Mass Balance" at the Tarfala Research Station in northern Sweden in 2012 describes a standard procedure for reanalysing mass-balance series (Zemp et al., 2013), based on best practices. The reanalysis procedures includes homogenisation of glaciological and geodetic balances, assessment of uncertainty, validation, and calibration, if necessary. It recommended that mass-balance series longer than 20 years should always be reanalysed.

Homogenisation of mass-balance series can be defined as the procedure to correct artefacts and biases that are not natural variations of the signal itself but originate from changes in instrumentation or changes in observational or analytical practice (Cogley et al., 2011). In the glaciological method, common inhomogeneities are changes in method (e.g. from contour line to altitude-profile method), changes in observational network, use of different glacier basins, and changes in area and elevation over time. In the geodetic method, inhomogeneity may stem from surveys using different sources and methods (e.g from analogue contour lines to digital point clouds), geo-referencing and projection of the data set, and software. When calculating the geodetic balance it is important that independent data or stable terrain outside the glaciers are used to check the individual DTMs. DTMs should be co-registered (Kääb, 2005) or even reprocessed from original survey data if needed (Koblet et al., 2010). Uncertainty is dependent not only on the standard error of the individual elevation differences but also on the size of the averaging area and the scale of the spatial correlation (Rolstad et al., 2009; Magnússon et al., 2016).

In Norway, the contribution of glacier melting to runoff instigated systematic mass-balance studies on several glaciers in the 1960s. Mass-balance programmes have been conducted on more than 40 glaciers for shorter or longer periods (Andreassen et al., 2005; Kjøllmoen et al., 2011).

In this paper, we compare homogenised glaciological and geodetic mass balance for the 10 Norwegian glaciers with long-term mass-balance series, whereof nine of them are considered key climate change reference series in Norway (Fleig et al., 2013) and seven of them are used as reference glaciers for the World Glacier Monitoring Service (WGMS, 2013). The data are widely used for modelling and statistical analyses and at different scales from local studies to global estimates (e.g. Rasmussen, 2004; Nesje and Matthews, 2012; Engelhardt et al., 2013; Trachsel and Nesje, 2015; Zemp et al., 2015).

The reanalysis of the mass-balance series included (i) homogenisation of both glaciological and geodetic observation series, (ii) uncertainty assessment, (iii) estimates of generic differences including estimates of internal and basal melt, (iv) validation, and, if needed, (v) partly calibration of massbalance series.

A large set of metadata, observations, calculations, and procedures were analysed: 454 years of glaciological massbalance data, 34 geodetic surveys/maps, and 21 periods of concurrent data. The analysed glaciers covered an area of $134 \mathrm{~km}^{2}$ ranging from 60.5 to $70.1^{\circ} \mathrm{N}$.

\section{Study glaciers}

The 10 glaciers selected for this study all have long-term mass-balance programmes and geodetic surveys that cover (the larger part of) the period with annual measurements (Table 1, Fig. 1). Glaciers with short-term series without concurrent geodetic surveys are not considered here. The glaciological series are continuous, except Langfjordjøkelen where glaciological measurements are lacking for 2 years (1994, 1995). The longest series is Storbreen where measurements began already in 1949; the shortest series are for Hansebreen, Austdalsbreen, and Langfjordjøkelen where measurements began in the late 1980s (Table 1). All glaciers are part of a glacier complex (thus sharing border with at least one other glacier flow unit) except for Storbreen (Andreassen et al., 2012b). The glaciers in southern Norway are located along a west-east transect, extending from a wet maritime climate, where Ålfotbreen and Hansebreen are located, to drier conditions in the interior, where Gråsubreen is located (Fig. 1). Engabreen and Langfjordjøkelen are located near the coast in the central and northern parts of Norway respectively and represent the glaciers with the lowest minimum and maximum elevation respectively. The glaciers range greatly in size from 2.1 (Gråsubreen) to $46.6 \mathrm{~km}^{2}$ (Nigardsbreen). One glacier, Austdalsbreen, calves into a regulated lake.

Norwegian glaciers have retreated throughout the twentieth century, although several periods of advance have also occurred. The most recent advance started in the late 1980s on many maritime glaciers but culminated around 2000 (Andreassen et al., 2012b). Mass-balance results show different behaviours of the 10 study glaciers. The northernmost glacier, Langfjordjøkelen, and the three interior (easternmost) glaciers in southern Norway (Storbreen, Hellstugubreen and Gråsubreen) have steadily lost mass during the past 50 years, greatest in Langfjordjøkelen (Andreassen et al., 2012a). The other six glaciers are maritime ice cap outlets that had a mass surplus, mainly due to higher snow accumulation in the 1990s, although all have lost mass since 2000 (Andreassen et al., 2005, 2012b; Kjøllmoen et al., 2011). There is significant variability in mass turnover between the study glaciers, from annual accumulation/ablation of about 1-2 $\mathrm{m}$ w.e. for the interior glaciers to $3-6 \mathrm{~m}$ w.e. for the maritime glaciers on the west coast (Andreassen et al., 2005). 
Table 1. Overview of the 10 glaciers used in this study, their characteristics, and glaciological and geodetic surveys used in this study. Period is period of mass-balance observations; years is number of mass-balance years up to and including 2014. Elevation minimum and maximum (m a.s.1.), slope (degree), and area $\left(\mathrm{km}^{2}\right)$ refer to the latest survey. NVE-ID is the ID in the latest inventory (Andreassen et al., 2012b). See Fig. 1 for location and Table 2 for details on geodetic surveys.

\begin{tabular}{|c|c|c|c|c|c|c|c|c|c|c|}
\hline No. & Name & NVE-ID & Period & Years & Elmin & Elmax & Area & Slope & Geodetic surveys & $n$ \\
\hline 1 & Ålfotbreen & 2078 & $1963-$ & 52 & 903 & 1382 & 4.5 & 10 & $1968,1988,1997,2010$ & 4 \\
\hline 2 & Hansebreen & 2085 & $1986-$ & 29 & 930 & 1327 & 3.1 & 9 & $1968,1988,1997,2010$ & 4 \\
\hline 3 & Nigardsbreen & 2297 & $1962-$ & 53 & 313 & 1952 & 46.6 & 8 & 1964, 1984, 2009, 2013 & 4 \\
\hline 4 & Austdalsbreen & 2478 & $1988-$ & 27 & 1200 & 1747 & 10.6 & 6 & 1988,2009 & 2 \\
\hline 5 & Rembesdalskåka & 2968 & $1963-$ & 52 & 1066 & 1854 & 17.3 & 4 & $1961,1995,2010$ & 3 \\
\hline 6 & Storbreen & 2636 & $1949-$ & 66 & 1400 & 2102 & 5.1 & 14 & 1968, 1984, 1997, 2009 & 4 \\
\hline 7 & Hellstugubreen & 2768 & $1962-$ & 53 & 1482 & 2229 & 2.9 & 13 & $1968,1980,1997,2009$ & 4 \\
\hline 8 & Gråsubreen & 2743 & $1962-$ & 53 & 1833 & 2283 & 2.1 & 12 & 1984, 1997, 2009 & 3 \\
\hline 9 & Engabreen & 1094 & $1970-$ & 45 & 89 & 1574 & 36.8 & 7 & $1968,2001,2008$ & 3 \\
\hline 10 & Langfjordjøkelen & 54 & 1989_* & 24 & 302 & 1050 & 3.2 & 13 & $1966,1994,2008$ & 3 \\
\hline Sum & & & & 454 & & & 132.2 & & & 34 \\
\hline
\end{tabular}

* 1994 and 1995 were not measured

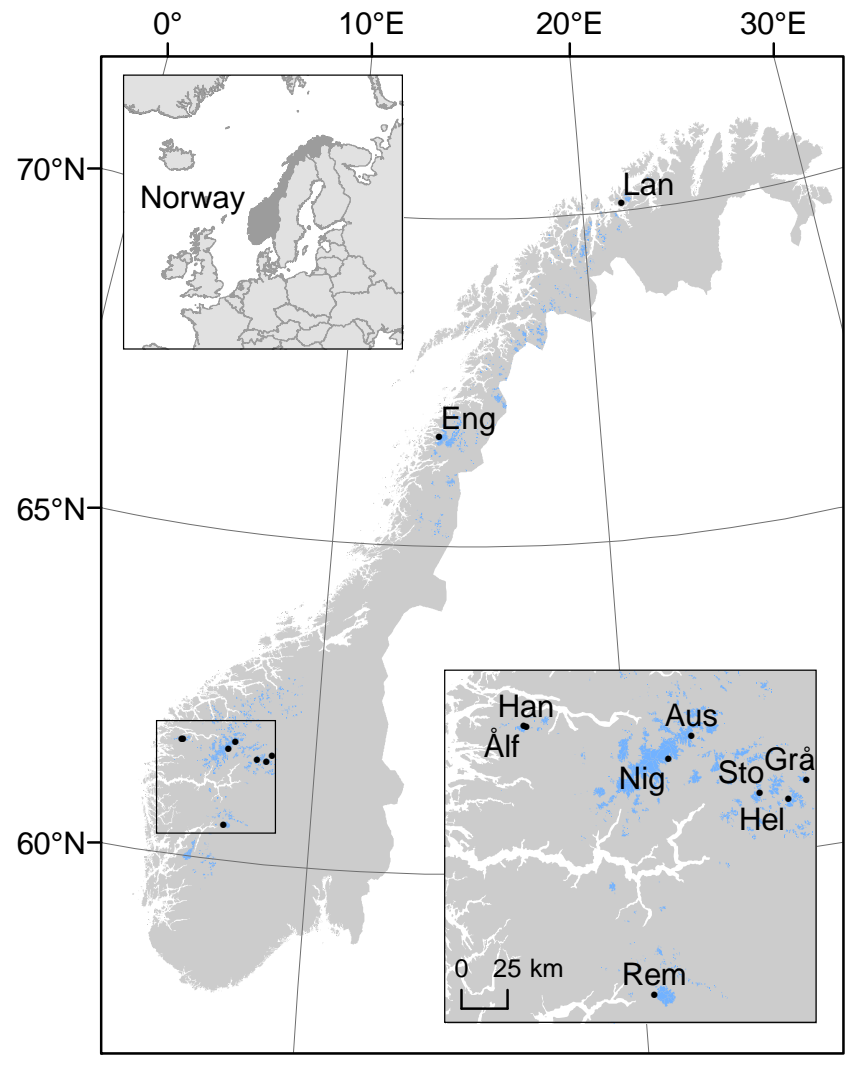

Figure 1. Location map of Norway showing the 10 study glaciers with long-term glaciological mass-balance series. Glaciers are shaded in blue. See Table 1 for details on the glaciers. The inset shows Norway's location in Europe and a zoom in on the eight glaciers in southern Norway.

\section{Data and methods}

In this chapter, we describe the data and methods used for calculating glaciological and geodetic mass balance and for the reanalysis undertaken. We describe the original data sets and the homogenisation of these, and we provide uncertainty assessments of systematic and random errors.

\subsection{Glaciological mass balance}

\subsubsection{Surface mass-balance observations}

The surface mass-balance series of the Norwegian Water Resources and Energy Directorate (NVE) contain annual (net), winter, and summer balances. Details on the observation programme including maps of the annual monitoring network are found in NVE's report series "Glaciological investigations in Norway" (e.g. Kjøllmoen et al., 2011; all reports are available at http://www.nve.no/glacier). Methods used to measure mass balance in the field have in principle remained unchanged over the years, although the number of measurements has varied (Andreassen et al., 2005). The winter balance is measured in spring by probing to the previous year's summer surface along regular profiles or grids, with typical values of 50-150 probings on each glacier every year (Fig. 2). Snow density is measured in pits and with coring at one or two locations at different elevations on each glacier. Stake readings and snow-depth corings are used to verify the probings. Summer and annual balances are obtained from stake measurements using density estimates of remaining snow (usually $600 \mathrm{~kg} \mathrm{~m}^{-3}$ ), melted firn $\left(650-800 \mathrm{~kg} \mathrm{~m}^{-3}\right.$ ), and ice $\left(900 \mathrm{~kg} \mathrm{~m}^{-3}\right.$; e.g. Kjøllmoen et al., 2011). The number of stake positions varies from glacier to glacier and through time, with typical values of 5-15. Stake density is highest on the smallest glacier, $6 \mathrm{~km}^{-2}$ on Gråsubreen, and 
Table 2. Geodetic surveys of the 10 glaciers used in this study. Under method, a refers to airborne, $\mathrm{P}$ to photogrammetry, and L to laser scanning. Under A/D, A refers to analogue constructed, later digitised, and D to digital constructed. Res. refers to resolution, contour interval on glacier for contours, resolution of DTM where regular grids were constructed, points $\mathrm{m}^{-2}$ for others. Contract refers to the contract number for aerial photos or for scanning reports. BNO is Blom and $\mathrm{T}$ is TerraTec.

\begin{tabular}{|c|c|c|c|c|c|c|c|c|}
\hline No. & Name & Year & Method & $\mathrm{A} / \mathrm{D}$ & Type & Res. & Contract & Date \\
\hline \multirow[t]{4}{*}{1,2} & Ålfotbreen \& & 1968 & $\mathrm{aP}$ & $\mathrm{D}$ & contours & $10 \mathrm{~m}$ & WF3210 & $1968-08-05$ \\
\hline & Hansebreen & 1988 & $\mathrm{aP}$ & $\mathrm{D}$ & contours & $10 \mathrm{~m}$ & FW9678 & 1988-09-07 \\
\hline & & 1997 & $\mathrm{aP}$ & $\mathrm{D}$ & DTM & $10 \mathrm{~m}$ & FW11440 & $1997-08-14$ \\
\hline & & 2010 & $\mathrm{aL}$ & $\mathrm{D}$ & points & $0.5 \mathrm{~m}^{-2}$ & $\mathrm{~T} 10067$ & 2010-09-02 \\
\hline \multirow[t]{4}{*}{3} & Nigardsbreen & 1964 & $\mathrm{aP}$ & $\mathrm{D}$ & points & $0.2 \mathrm{~m}^{-2}$ & WF1171 & 1964-09-02 \\
\hline & & 1984 & $\mathrm{aP}$ & A & contours & $10 \mathrm{~m}$ & FW8310 & $1984-08-10$ \\
\hline & & 2009 & $\mathrm{aL}$ & $\mathrm{D}$ & points & $0.3 \mathrm{~m}^{-2}$ & BNO097044 & $2009-10-17$ \\
\hline & & 2013 & $\mathrm{aL}$ & $\mathrm{D}$ & points & $1 \mathrm{~m}^{-2}$ & $\mathrm{~T} 40235$ & 2013-09-10 \\
\hline \multirow[t]{2}{*}{4} & Austdalsbreen & 1988 & $\mathrm{aP}$ & $\mathrm{A}$ & contours & $10 \mathrm{~m}$ & FW9659 & $1988-08-10$ \\
\hline & & 2009 & $\mathrm{aL}$ & $\mathrm{D}$ & points & $0.3 \mathrm{~m}^{-2}$ & BNO097044 & $2009-10-17$ \\
\hline \multirow[t]{3}{*}{5} & Rembesdalskåka & 1961 & $\mathrm{aP}$ & A & contours & $10 \mathrm{~m}$ & WF1230 & 1961-08-31 \\
\hline & & 1995 & $\mathrm{aP}$ & $\mathrm{D}$ & contours & $20 \mathrm{~m}$ & FW11862 & $1995-08-31$ \\
\hline & & 2010 & $\mathrm{aL}$ & $\mathrm{D}$ & points & $0.5 \mathrm{~m}^{-2}$ & $\mathrm{~T} 10063$ & 2010-09-30 \\
\hline \multirow[t]{4}{*}{6} & Storbreen & 1968 & $\mathrm{aP}$ & $\mathrm{A}$ & contours & $10 \mathrm{~m}$ & WF3207 & $1968-08-27$ \\
\hline & & 1984 & $\mathrm{aP}$ & $\mathrm{A}$ & contours & $10 \mathrm{~m}$ & FW8336 & $1984-08-24$ \\
\hline & & 1997 & $\mathrm{aP}$ & $\mathrm{D}$ & DTM & $5 \mathrm{~m}$ & FW12173 & 1997-08-08 \\
\hline & & 2009 & $\mathrm{aL}$ & $\mathrm{D}$ & points & $0.3 \mathrm{~m}^{-2}$ & BNO097044 & 2009-10-17 \\
\hline \multirow[t]{4}{*}{7} & Hellstugubreen & 1968 & $\mathrm{aP}$ & $\mathrm{A}$ & contours & $10 \mathrm{~m}$ & WF3207 & $1968-08-27$ \\
\hline & & 1980 & $\mathrm{aP}$ & A & contours & $10 \mathrm{~m}$ & FW6555 & $1980-09-26$ \\
\hline & & 1997 & $\mathrm{aP}$ & $\mathrm{D}$ & DTM & $5 \mathrm{~m}$ & FW12173 & 1997-08-08 \\
\hline & & 2009 & $\mathrm{aL}$ & $\mathrm{D}$ & points & $0.3 \mathrm{~m}^{-2}$ & BNO097044 & 2009-10-17 \\
\hline \multirow[t]{3}{*}{8} & Gråsubreen & 1984 & $\mathrm{aP}$ & A & contours & $10 \mathrm{~m}$ & FW8330 & $1984-08-23$ \\
\hline & & 1997 & $\mathrm{aP}$ & $\mathrm{D}$ & DTM & $5 \mathrm{~m}$ & FW12173 & $1997-08-08$ \\
\hline & & 2009 & $\mathrm{aL}$ & $\mathrm{D}$ & points & $0.3 \mathrm{~m}^{-2}$ & BNO097044 & 2009-10-17 \\
\hline \multirow[t]{3}{*}{9} & Engabreen & 1968 & $\mathrm{aP}$ & A & contours & $10 \mathrm{~m}$ & WF3205 & $1968-08-25$ \\
\hline & & 2001 & $\mathrm{aL}$ & $\mathrm{D}$ & points & $0.7 \mathrm{~m}^{-2}$ & Topscan GmbH & 2001-09-24 \\
\hline & & 2008 & $\mathrm{aL}$ & $\mathrm{D}$ & points & $2.6-6.0 \mathrm{~m}^{-2}$ & BNO08797 & 2008-09-02 \\
\hline \multirow[t]{3}{*}{10} & Langfjordjøkelen & 1966 & $\mathrm{aP}$ & $\mathrm{D}$ & contours & $10 \mathrm{~m}$ & WF1800 & 1966-07-11 \\
\hline & & 1994 & $\mathrm{aP}$ & $\mathrm{D}$ & contours & $10 \mathrm{~m}$ & FN94168 & 1994-08-01 \\
\hline & & 2008 & $\mathrm{aL}$ & $\mathrm{D}$ & points & $0.6 \mathrm{~m}^{-2}$ & BNO07771 & 2008-09-02 \\
\hline
\end{tabular}

lowest on the largest glaciers, $0.2 \mathrm{~km}^{-2}$ on Nigardsbreen and Engabreen. The annual calving from Austdalsbreen is calculated from measured ice velocity near the terminus, surveyed autumn terminus positions, and estimated mean ice thickness (Elvehøy, 2011), following Funk and Rötlisberger (1989).

To calculate glacier-wide winter $\left(B_{\mathrm{w}}\right)$, summer $\left(B_{\mathrm{S}}\right)$, and annual $\left(B_{\mathrm{a}}\right)$ balances, the point measurements are interpolated to area-averaged values. In the first years this was done by the contour line method, while since the middle/end of the 1980s this has been done using the profile method. The shift in method was mainly a consequence of a reduction in the observing network on many of the maritime glaciers. Furthermore, investigations had showed that annual balance measured at stakes correlated well with glacier-wide annual balance and that the fieldwork could be simplified (Roald, 1973). In the contour line method, the point measurements were plotted on a map and isolines of mass balance were drawn for both winter and summer balances (Fig. S1 in the Supplement). The areas between adjacent isolines within each altitudinal interval $(50$ or $100 \mathrm{~m})$ were integrated using a planimeter, and the total amount of accumulation and ablation was calculated for each altitude interval. In the profile method, the point measurements vs. altitude are plotted and interpolated balance profiles are drawn to obtain massbalance values for each altitudinal interval (Fig. 3). The elevation of point measurements and area distribution are taken from the most recent map/digital terrain model of the glacier. When a new map has been constructed, it was used for the 

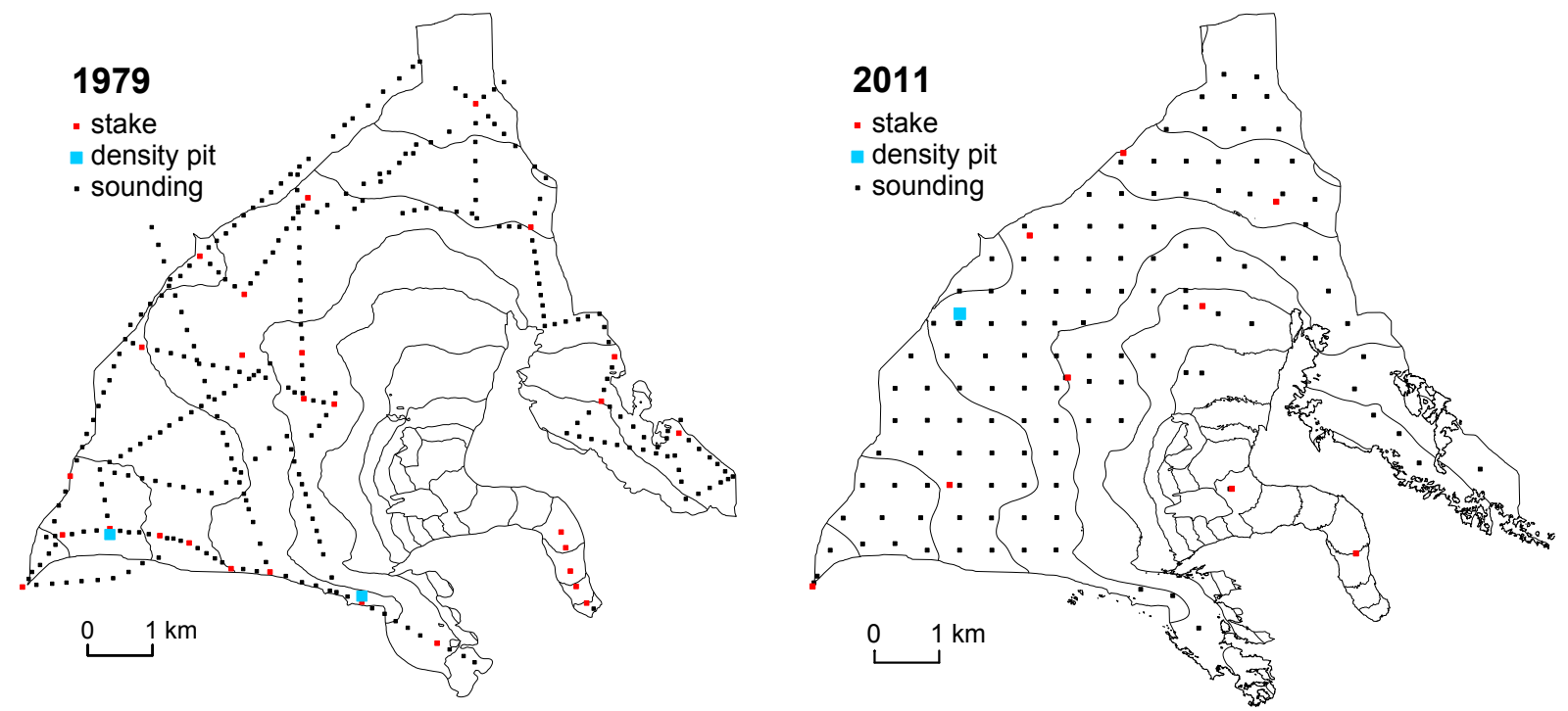

Figure 2. Typical stake network and snow depth soundings for Nigardsbreen. Non-glaciated areas within the basin are shaded in grey. The network in 1979 is representative for the period 1962-1981, whereas 2011 is representative for 2009-2014. The glacier outlines are from 1974 and 2013.

calculations from then and onwards. However, there may be considerable time lag (up to 30 years) between the massbalance year and the reference area used for calculating mass balance.

Glaciological balances are reported as conventional surface balances, i.e. internal and basal balances have not been part of the observational programme and are not accounted for in the published mass-balance records.

\subsubsection{Homogenisation of surface mass balance}

Homogenising a surface mass-balance series may involve different steps and will differ from glacier to glacier according to the richness of the data material as well as the time available for the analysis. A thorough homogenising process was applied to four of the glaciers (Nigardsbreen, Engabreen, Alfotbreen, and Hansebreen), as the first comparison of geodetic and glaciological balances indicated rather large discrepancies between the methods (Elvehøy, 2016; Kjøllmoen, 2016a, b). This detailed homogenisation process included going through the data material for each year to search for inhomogeneities and possible biases in the data calculations. The process included digitisation of point measurements, recalculating the mass balance using homogenised drainage divides, density conversion, and recalculating from contour to profile method for the earlier years. For the other six glaciers, a less detailed procedure was followed, typically including homogenisation of the drainage divide and areaaltitude distributions. For Austdalsbreen the calculation procedure of losses due to calving was also homogenised.

In the following section, we describe in more detail the homogenisation of the area-altitude distribution, the change from the contour map method to the profile method, and the calving of Austdalsbreen.

\section{Area-altitude distribution}

The annual mass-balance calculations were based on a series of maps for each glacier. When a new map or DTM became available some time after the survey, the mass balance was calculated from then on using the new map for the stake and sounding elevations and the area-altitude distribution. The change of glacier area and elevation over time is an inhomogeneity common to all mass-balance calculations (Holmlund et al., 2005; Zemp et al., 2013). To minimise the effects of the changing elevation distribution on the results, we recalculated glacier-wide balance values for the period of record using both area-altitude distributions. Two approaches were tested: (1) shift, which simply uses the older map for first half of the period and then the newer map for the second half; or (2) linear weighting, which calculates $B_{\mathrm{a}}$ for all years in the period using both area-altitude distributions and linearly time-averages between them.

The advantage of approach (2) is that the values are interpolated through time and inhomogeneity is smoothed out. However, for several of the glaciers there is not a linear trend in glacier change. Langfjordjøkelen is the glacier with the strongest thinning and retreat of the 10 study glaciers (Andreassen et al., 2012a) and is expected to have the largest sensitivity to the DTM used for the mass-balance results. A comparison between the two methods for Langfjordjøkelen and Storbreen shows that the difference between methods 1 and 2 is small for the cumulative $B_{\mathrm{a}}$ for both glaciers: $-0.18 \mathrm{~m}$ w.e. for Langfjordjøkelen for the period 1995-2008 


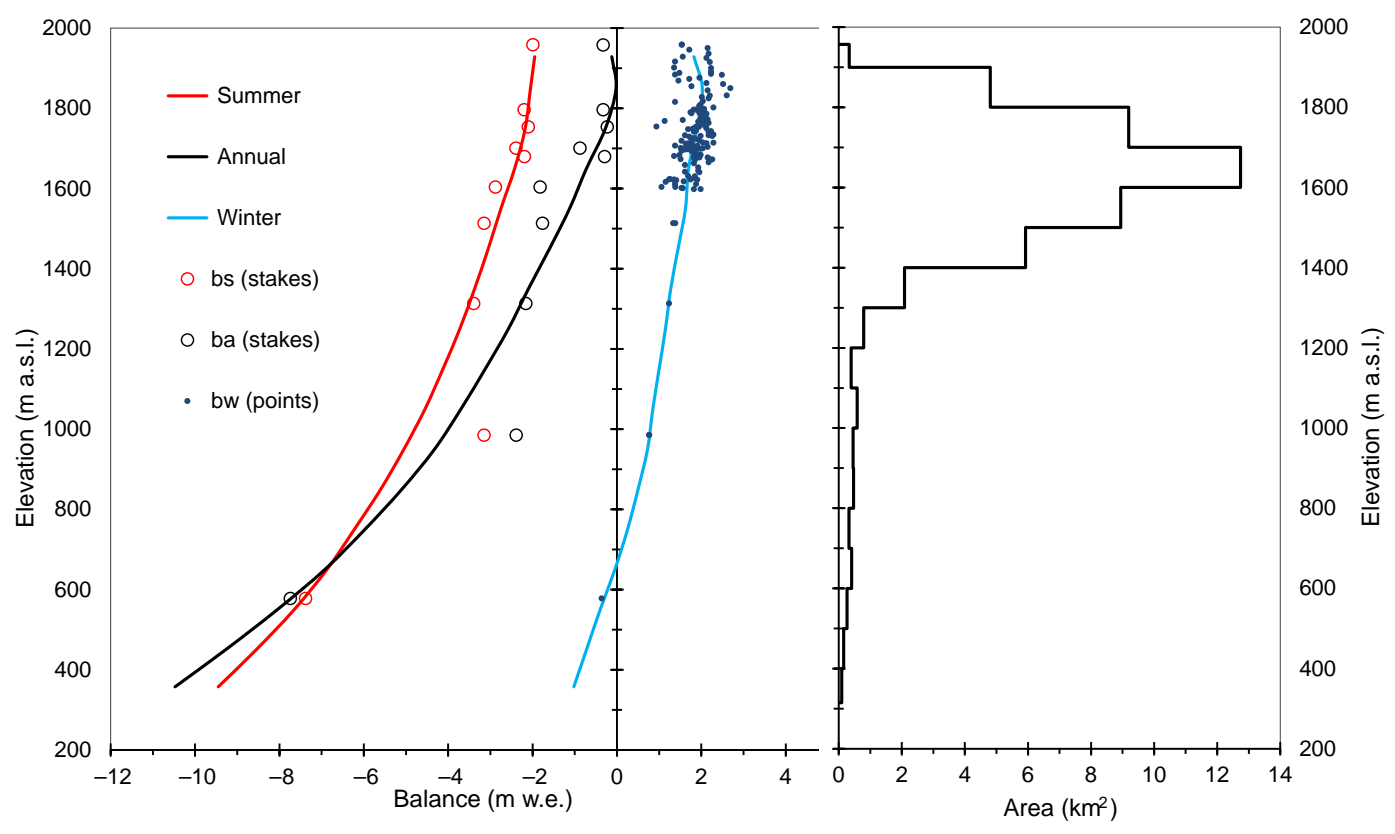

Figure 3. Illustration of the profile method for Nigardsbreen 2003. The altitudinal winter, summer, and annual mass-balance curves and point values for $b_{\mathrm{w}}($ red $\circ), b_{\mathrm{S}}\left(\circ\right.$, black), and $b_{\mathrm{a}}$ (blue $\bullet$ ), together with average $b_{\mathrm{w}}$ (blue $\square$ ) for each $100 \mathrm{~m}$ altitude interval are plotted vs. altitude.

and $0.01 \mathrm{~m}$ w.e. for Storbreen for the period 1998-2009 (Table 3). Results further reveal that the difference in $B_{\mathrm{a}}$ values for individual years varied between 0.09 and $-0.06 \mathrm{~m}$ w.e for Langfjordjøkelen and between 0.01 and $-0.02 \mathrm{~m}$ w.e. for Storbreen. For simplicity, approach (1) was used for the final calculations for all glaciers. For glaciers with strong non-linear changes, normalised front variation series might be used to weight the interannual area changes (Zemp et al., 2013), but this was not used in this study.

\section{Contour map to profile method}

In the 1980s, a simplification of the observation programme was carried out after statistical analysis of the previous years' accumulation and ablation patterns, especially at large outlet glaciers like Nigardsbreen and Engabreen (Andreassen et al., 2005). The interpolation method was also shifted from the contour to the profile method at the end of the 1980s. However, the profile method can be sensitive to the altitudinal coverage and the spatial pattern of observations (EscherVetter et al., 2009). The profile method relies on the consistency of the annual mass-balance gradient. Analyses of the mass-balance gradients show vertical profiles of annual and seasonal mass balance are remarkably linear and vary little from year to year (Rasmussen, 2004; Rasmussen and Andreassen, 2005). Studies of Lemon Creek and Taku Glacier, Alaska, show also a consistency of the annual balance gradient (Pelto et al., 2013). Usually the profile method has been used by drawing the area-altitude mass-balance curves manually for our mass-balance data. To test the sensitivity of the manual drawing on the mass-balance results, two of the au- thors used the point data for Engabreen to draw curves for 7 years, 2002-2008. In this period, the glacier had only one stake at the tongue at $\sim 300 \mathrm{~m}$ a.s.l. and then about six stakes on the ice plateau from $\sim 950$ to $1350 \mathrm{~m}$ a.s.l. The profile curves were then compared with the curves drawn manually by the principal investigator and there were only minor differences between the drawn curves. The resulting annual $B_{\mathrm{w}}, B_{\mathrm{s}}$, and $B_{\mathrm{a}}$ values calculated from the profiles were in good agreements and were typically within $\pm 0.1 \mathrm{~m}$ w.e. $\mathrm{a}^{-1}$ of each other with no outliers. Thus, this test revealed little sensitivity to the subjective judgement in the manual drawing of the annual curves in the profile method. More automated procedures were tested but were not found suitable due to the data material available.

\section{Calving}

For Austdalsbreen, a map from 1966 was originally used for 1988-2008 and the map from 2009 since 2009. In the homogenisation, mass balance was recalculated using the 2009 ice divide for all years, the 1988 glacier outline and area-altitude distribution for 1988-1998, and the 2009 outline and area-altitude distribution from 1999. Due to construction of a hydropower reservoir in front of Austdalsbreen in 1988-1989, the lake level was changed from a fixed level around $1156 \mathrm{~m}$ a.s.l. to a varying level between 1150 and $1200 \mathrm{~m}$ a.s.l. The lowest part of the glacier calved off during the first 2 years. Thus, in the homogenisation this was accounted for by removing the calved off part below $1200 \mathrm{~m}$ a.s.l. $\left(0.093 \mathrm{~km}^{2}\right)$ from the area-altitude distribution 
Table 3. Example of sensitivity of mass-balance results of Langfjordjøkelen (1994-2008) and Storbreen (1997-2009) using area-altitude distributions from 2 different years, using only the first year or only the second year throughout, and homogenising them using (1) a stepwise shift (step) halfway through the period or (2) by linearly time weighting (linear) them. $B_{\mathrm{S}}$ and $B_{\mathrm{a}}$ are averages (m w.e. $\mathrm{a}^{-1}$ ) for the period of record, and $\sum B_{\mathrm{a}}$ is the cumulative sum of $B_{\mathrm{a}}$ for the period (m w.e.).

\begin{tabular}{|c|c|c|c|c|c|c|c|c|}
\hline \multirow{3}{*}{$\begin{array}{l}\text { m } \\
\text { w.e. }\end{array}$} & \multicolumn{4}{|c|}{ Langfjordjøkelen } & \multicolumn{4}{|c|}{ Storbreen } \\
\hline & only & only & (1) & (2) & only & only & (1) & (2) \\
\hline & 1994 & 2008 & shift & linear & 1997 & 2009 & shift & linear \\
\hline$B_{\mathrm{W}}$ & 1.94 & 2.00 & 1.98 & 1.98 & 1.44 & 1.43 & 1.43 & 1.43 \\
\hline$B_{\mathrm{S}}$ & -3.18 & -3.07 & -3.10 & -3.11 & -1.95 & -1.95 & -1.95 & -1.95 \\
\hline$B_{\mathrm{a}}$ & -1.24 & -1.07 & -1.12 & -1.14 & -0.51 & -0.52 & -0.52 & -0.52 \\
\hline$\sum B_{\mathrm{a}}$ & -16.13 & -13.87 & -14.58 & -14.76 & -6.11 & -6.27 & -6.20 & -6.19 \\
\hline
\end{tabular}

from 1990. As part of the homogenisation, the annual calving volumes were also recalculated.

\subsubsection{Example: homogenisation of the Nigardsbreen surface mass-balance record}

Annual glaciological mass-balance measurements began on Nigardsbreen in 1962 (Østrem and Karlén, 1962). NVE has carried out the measurements in all years, but many people have been involved in the fieldwork during this period, and several principal investigators have been responsible for the calculations. The original published results show positive mass balance from 1962 to 1988 (4.5 mw.e.), a large surplus from 1989 to 2000 (12.9 mw.e.), and near balance (a small deficit) from 2001 to 2013 ( $-0.96 \mathrm{~m}$ w.e.). Detailed glacier maps have been constructed from aerial photographs taken in 1964, 1966/1974 (combined), and 1984 and by laser scanning in 2009 and 2013. The original glaciological massbalance series were compared with geodetic mass balances for the periods 1964-1984 and 1984-2013, and they revealed large discrepancies. Due to uncertainties of the original map from the 1964 photos constructed in 1965, a new digital point cloud was constructed from the 1964 photos in 2014. The combined 1966/1974 map was made using photos from the 2 years; due to the large time gap between the photos and uncertainties in which parts mapped by which photos, the map was not used for the geodetic calculations.

All point measurements of snow depths and stakes were identified in data reports and maps and given positions and altitudes from the relevant DTM. The re-calculation was based on the profile method within the hydrological basin and with the current DTM and ice divide from 2009/2013. The review of the historic data sets and the re-calculation process also revealed some errors in the original mass-balance calculations in some years, e.g. the handling of summer snow fall and density conversions. These errors were corrected in the re-calculations.

The glaciological mass-balance methodology has changed through the period of measurements. Five types of inhomo- geneities were identified and accounted for in the homogenisation process (Table S1 in the Supplement).

\section{Contour line method}

From 1962 to 1988 , both winter and summer balances were calculated using the contour line method. From 1989, the altitudinal mass-balance curves were constructed by plotting point measurements vs. altitude. Accordingly, the homogenisation involved re-calculation of the period 1962-1988 using the profile method. The curves were manually drawn between the point measurements.

\section{Area-altitude distribution}

The original mass-balance calculations were based on areaaltitude distribution from five maps (1964, 1974, 1984, 2009 and 2013). There were considerable time lags between the mass-balance data and the map used for the calculations. Over the years from 1964 to 2013, Nigardsbreen had periods of both shrinking and growing. Hence, the step approach was used where the period between two mappings were divided in two, and each map was applied to half of the period before the mapping year and half of the period after the mapping year. Accordingly, the homogenisation involved re-calculation of the periods 1969-1973, 19791987, and 1997-2012. This resulted in small changes of the annual $B_{\mathrm{w}}, B_{\mathrm{s}}$, and $B_{\mathrm{a}}$ values, keeping the DTM for the start year for the whole period instead of the step approach would have resulted in a more positive cumulative balance for the first period 1964-1974 (+0.42 m w.e.), nearly no change for 1975-1984 ( $+0.05 \mathrm{~m}$ w.e.), more negative for $1985-2009$ ( $-0.18 \mathrm{~m}$ w.e.), and nearly no change for 2010 2013 (+0.05 m w.e.). The overall change in balance after homogenising the area-altitude distribution was small $(0.31 \mathrm{~m}$ w.e) for Nigardsbreen and has thus little impact on the cumulative mass balance. 


\section{Snow density conversion}

Winter balance calculations are based on measurements of snow depths and snow density. The converting procedure from snow depth to water equivalent has varied through the years. For the first 4 decades (from 1960s to 1990s) a precise documentation of the converting procedure is lacking. However, for some of the years, it appears that an average density $\left(\rho_{\mathrm{av}}\right)$ of the snow pack was used for each snow depth $\left(c_{\mathrm{a}}\right)$, expressed as $b_{\mathrm{w}}=c_{\mathrm{a}}(\mathrm{m}) \times \rho_{\mathrm{av}}\left(\mathrm{kg} \mathrm{m}^{-3}\right) / 1000$. For some other years, a unique snow density for each snow depth was estimated based on the measured density profile. From 2001 and onwards a snow density function derived from the snow density measurements was used to convert snow depths to snow water equivalents. Usually a third degree (or second) polynomial was used, expressed as $b_{\mathrm{w}}=a \times c_{\mathrm{a}}^{3}+b \times c_{\mathrm{a}}^{2}+c \times c_{\mathrm{a}}+d$ ( $a, b, c$, and $d$ are coefficients). In the homogenisation process a density function was used for 40 of the 52 years. For 12 of the years, the original water equivalent values $\left(b_{\mathrm{w}}\right)$ were kept due to lacking data or difficulties in data interpretation.

\section{Ice divide}

The ice divide used in the calculations was made for each map and thus varied between the mappings. The DTM derived from the laser scanning is considered much more accurate than the DTM derived from the aerial photos used for the older maps, in particular in the flat accumulation area where the ice divide of the glacier is located. Although the ice divide may have moved through time, it is not possible to determine this with the map material available. Thus, assuming that the ice divide had been unchanged over the period of record, the divide constructed from the laser-scanned DTMs from 2009 and 2013 were considered the most accurate (a comparison of 2009 and 2013 divides showed similar divides, a combination of them was used to obtain full spatial coverage). Accordingly, the homogenisation involved re-calculation of the period 1962-2012, using the ice divide from 2009/2013.

\section{Glacier boundaries}

From 1962 to 1967, the mass balance for Nigardsbreen was calculated using the glaciological basin, i.e. the area draining ice to the glacier terminus, thus excluding the southeastern and northeastern fringes that do not flow into the main glacier (Fig. 4). The hydrological basin, i.e. the surface area draining water to the lake, Nigardsbrevatn, has been used for the glaciological mass-balance calculations since 1968. The influence on the volume change calculations of the different drainage basins was checked for the period 1962-1967 and the area-altitude distribution from DTM1964 using both the hydrological basin $\left(48.3 \mathrm{~km}^{2}\right)$ and the glaciological basin $\left(40.9 \mathrm{~km}^{2}\right)$. The test revealed almost identical results for the average annual balance but with small interannual variations. The hydrological drainage basins based on the surveys from
1964, 1984, 2009, and 2013 are quite similar in both area extent and pattern but not exactly congruent. The ice divide from 2009/2013 was used for all four DTMs. However, different interpretations and veritable changes of the ice margin reveal four drainage basins with some minor differences. The hydrological basin area was $48.3 \mathrm{~km}^{2}$ (1964), $48.1 \mathrm{~km}^{2}$ (1984), $47.2 \mathrm{~km}^{2}$ (2009), and $46.6 \mathrm{~km}^{2}$ (2013) respectively. The 1964 basin has the greatest area and the most extended frontal ice margin (Fig. 4).

\subsection{Internal mass-balance calculation}

Internal and basal balances are not measured, but they need to be accounted for when comparing glaciological with geodetic balances. Melting occurs within a glacier if the temperature is at melting point and there is a source of energy (Cuffey and Paterson, 2010). Flowing water that is warmer than the ice may cause melting by direct heat transfer or by loss of potential energy, which dissipates as heat (Cuffey and Paterson, 2010). Theoretic calculations has suggested that internal ablation can be a significant term for Nigardsbreen (Oerlemans, 2013) and can contribute as much as $10 \%$ to the total ablation of Franz Josef Glacier (Alexander et al., 2011). In this study, we estimated internal and basal ablation due heat of dissipation based on Oerlemans (2013). Ablation due to rain (Alexander et al., 2011) was considered negligible, as most of this melting affects snow, firn, and ice at the surface rather than the subglacial and basal system. Other terms such as geothermal heat and refreezing of melt water below the previous summer' surface were also considered negligible as they were assumed to be insignificant in this climate and will to some degree cancel out.

Melt by dissipation of energy, $M$, was calculated by the formula

$M=\frac{\sum_{h} g P_{h} A_{h}\left(h-b_{L}\right)}{A L_{m}}$,

where $g$ is the acceleration of gravity, $h$ is mean elevation of elevation interval used in surface mass-balance calculations, $P_{h}$ is precipitation at $h, A_{h}$ is glacier area of elevation interval $h, b_{L}$ is bed elevation at glacier snout, $A$ is total glacier area, and $L_{m}$ is latent heat of fusion. This formula is based on Eqs. (8) and (9) in Oerlemans (2013), but it calculates the effect at each elevation interval used in surface mass balance for the given glacier. Precipitation was calculated as a linear function of elevation. Daily precipitation was extracted from data version 1.1.1 at www.senorge.no (Saloranta, 2014). The seNorge (in English "see Norway") data set provides daily gridded data of temperature, precipitation, and snow amounts in Norway from 1957 to present using data from all available stations of the Meteorological Institute (e.g. Saloranta, 2012). 


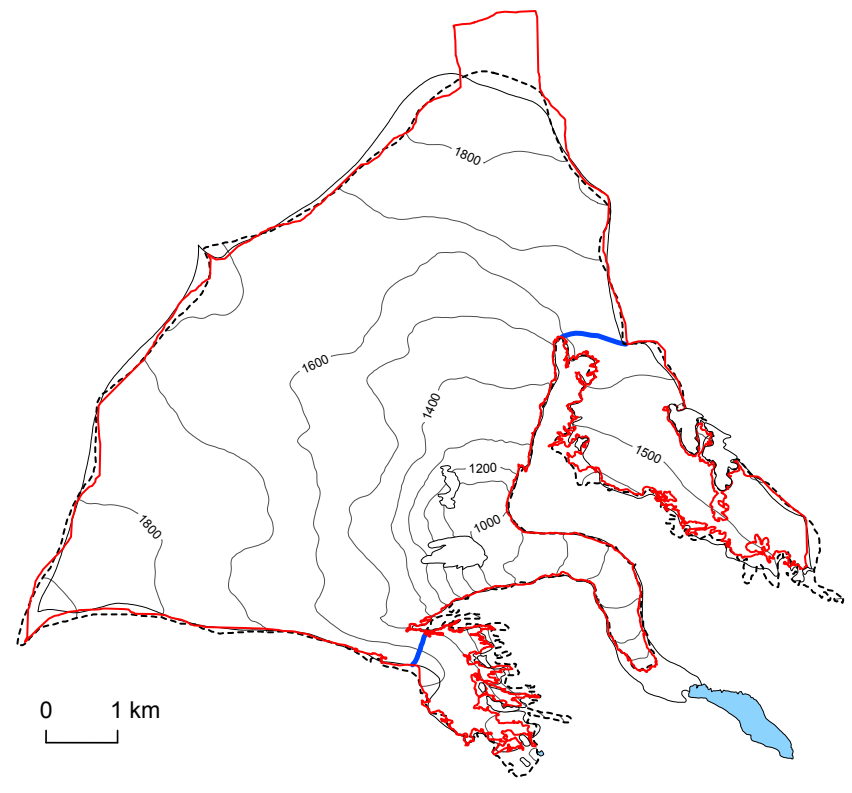

Figure 4. The hydrological basins of Nigardsbreen. The basin is derived from the 2013 mapping in red; the dotted line shows the 1984 extent and basin; the black solid line shows the 1964 extent. The glaciological divides used in the first years are marked in blue. Elevation contours are $100 \mathrm{~m}$ derived from the 2013 DTM. Lake Nigardsbrevatn is shaded in turquoise.

\subsection{Geodetic mass balance}

\subsubsection{Surveys}

The geodetic surveys used in this paper were constructed from different sources and methods (Table 2). Before 2001, surveys were based on vertical aerial photos. Most of the surveys from 1950s to the 1980s are contour maps constructed from vertical aerial photographs using analogue photogrammetry. These analogue contour maps were digitised at the end of the 1990s. In the 1990s, digital terrain models or digital contour maps were usually constructed directly from the aerial photos. Since the first laser scanning of Engabreen in 2001 (Geist et al., 2005), all surveys of the glaciers used in this study have been made from airborne laser scannings, usually in combination with concurrent air photos. A few maps have been reconstructed (the 1968 map of Alfotbreen and Hansebreen and 1964 map of Nigardsbreen; see Table 2) to improve the surveys.

\subsubsection{Mass-balance calculations}

The differences between repeated DTMs should reveal the change in elevation between the corresponding times of data acquisition and not change due to misalignments of the DTMs. To check for this, for each glacier, the older DTMs were compared with the most recent laser-scanned DTM to check for misalignment and shifts. In the following, we describe the homogenisation and calculation procedure. All GIS-based data processing of maps and DTMs by NVE was done using ArcGIS software $\left(\right.$ ESRI $\left.^{\odot}\right)$, Python (Python Software Foundation), or Surfer software version 12 (Golden Software, Inc. 2014).

The following approach was used to test the quality of the DTMs. The latest laser-scanned elevation point clouds were considered the most accurate and used to create a 5 or $10 \mathrm{~m}$ reference DTM. For surveys available as digitised contour maps, the contour lines were converted to elevations points at vertices along contour lines. Elevation differences were calculated between the reference DTM and the elevation points. For gridded maps, elevation differences, $\mathrm{d} H$, were calculated by DTM differencing on a cell by cell basis. The vertical elevation differences, $\mathrm{d} H$, were compared outside the glacier in stable terrain.

The DTMs and contour maps were first checked for horizontal and vertical shifts by plotting vertical difference of the terrain, $\mathrm{d} H$, outside the glacier border against aspect and $\mathrm{d} H / \tan \alpha$ against aspect, where $\alpha$ is the angle of the slope (Kääb, 2005; Nuth and Kääb, 2011). In one case, Engabreen 1968, a systematic horizontal shift of $12 \mathrm{~m}$ was detected and the map was shifted prior to the further analysis.

To decide whether a DTM should be shifted in vertical direction, a mean error, $\varepsilon$, was calculated from the standard error, $\sigma$, of the elevation differences, $\mathrm{d} H$ :

$\varepsilon=z \frac{\sigma}{\sqrt{n}}$

where $n$ is the number of independent samples. For a contour map we used $n$ as the number of contours from which we compared the points; for a map constructed from aerial photographs we used $n$ as the number of photos.

Only points with slopes less than $30^{\circ}$ were considered. Orthophotos and glacier extents were checked to avoid comparing points that were snow covered in one of the surveys. We chose $z$ as 1.96 for achieving a $95 \%$ confidence interval assuming that the data are normally distributed. Furthermore, we only shifted if $\varepsilon<\overline{\mathrm{d} H}$ and $\overline{\mathrm{d} H}>1 \mathrm{~m}$. This may be considered conservative, but contour points outside a glacier are not necessarily representative for the glacier surface.

For the further processing, DTMs were created from the contour maps using digitised vertices along the contour lines together with elevation points from the map to convert contour maps to regular grids of 5 or $10 \mathrm{~m}$ cell size aligning to the reference DTM. The interpolation function "Topo to Raster" (ArcGIS; Hutchinson, 1989; Hutchinson and Dowling, 1991) or kriging (Surfer) were used to obtain surface grids. Various interpolation functions in ArcGIS and Surfer were tested, but they had little influence on the results. In a test, the results for Nigardsbreen 1984-2013 were calculated from the contour map (1984) and laser data (2013) to final DTM difference map with both kriging in Surfer and Topo to Raster in ArcGIS, and they gave near identical resulting elevation difference (within $\pm 0.1 \mathrm{~m}$ ). 
Surface elevation changes were calculated for all glaciers and periods by subtracting the DTMs on a cell-by-cell basis.

To compare the geodetic mass balance with the glaciological balance, the volume change of ice, snow, and firn over a period needs to be converted to mass using a density estimate. Observations of firn thickness and density are in general few and only exist for a few point locations in mainland Norway. In May 1987, a $47 \mathrm{~m}$ core was drilled at the highest elevation at Nigardsbreen, revealing a firn/ice transition at $30 \mathrm{~m}$ depth (Kawamura et al., 1989). The snow depth was about $6 \mathrm{~m}$ giving a firn layer of $24 \mathrm{~m}$ at this point. The density of the firn varied from 550 to $750 \mathrm{~kg} \mathrm{~m}^{-3}$. At the top of Rembedalskåka at 1850 ma.s.1., in the autumn of 1970 , several firn cores were drilled 7 to $10 \mathrm{~m}$ into firn probably dating back to 1964. The firn density increased from 600 to $700 \mathrm{~kg} \mathrm{~m}^{-3}$ in these cores (Laumann, 1972). Unfortunately, no repeat profiles are available to determine changes in the density over time.

Since few observations of firn thicknesses and densities are available, it is a common approach to assume that the density profile from the surface to the firn-ice transition remained unchanged between the surveys following Sorge's law (Bader, 1954). Often an ice density of $900 \mathrm{~kg} \mathrm{~m}^{-3}$ has been used to convert volume to mass (e.g. Andreassen, 1999; Haug et al., 2009); other studies have used values of $917 \mathrm{~kg} \mathrm{~m}^{-3}$ (Nuth et al., 2010) or $860 \pm 60 \mathrm{~kg} \mathrm{~m}^{-3}$ (Zemp et al., 2010). Huss (2013) showed that a density conversion factor, $f_{\Delta V}$, of $850 \pm 60 \mathrm{~kg} \mathrm{~m}^{-3}$ is appropriate to convert volume change to mass change for a wide range of conditions. However, for short time intervals ( $\leq 3$ years), periods with limited volume change, or changing mass-balance gradients, the conversion factor can vary much more. Following Huss (2013) we estimated the density correction factor, $f_{\Delta V}$, for each period of the 10 glaciers by

$f_{\Delta V}=\frac{\Delta_{\rho} V}{\Delta V}+\rho$

where $\rho$ is the bulk density of the glacier including ice, snow, and firn, and $\Delta \rho$ and $\Delta V$ is the change in bulk density and volume respectively between the two periods. We used observed ice thicknesses and volume changes and estimated firn thicknesses, density, and firn area extent based on calculated area-accumulation ratios and best estimate taking into account the annual balances in the periods prior to the surveys. Obtained values varied between 800 and 899 and thus within $850 \pm 60$, with the exception of one period for Gråsubreen (1984-1997) that had a lower value. Whereas the firn area can be estimated somewhat more precisely due to observed annual balances and estimates of equilibrium-line altitude (ELA) and accumulation-area ratio (AAR) and air photos, the values of firn densities and firn depths can only be estimated. We therefore decided to use a density conversion factor, $f_{\Delta V}$, of $850 \pm 60 \mathrm{~kg} \mathrm{~m}^{-3}$.
We thus calculated the geodetic mass balance, $B_{\text {geod }}$, by

$B_{\text {geod }}=\frac{\Delta V \times f_{\Delta V}}{\bar{A}}$

where $\bar{A}$ is average glacier area of the two surveys assuming a linear change in time. The glacier area derived from the homogenised ice divides based on the latest laser scanning was used as calculation basis.

Finally, the geodetic results were corrected to account for ablation and accumulation between the glaciological and the geodetic surveys. The correction was estimated by using stake readings if available, snow information from www. senorge.no, or modelled using a simple mass-balance model with input of temperature and precipitation data from nearby meteorological stations (downloaded from www.eklima.no). The latter approach was also used for estimated the 2 years (1994 and 1995) of lacking data at Langfjordjøkelen.

\subsection{Uncertainty assessment}

Uncertainties in glaciological and geodetic mass balances may be systematic or random. Our uncertainty assessment followed the approach recommended by Zemp et al. (2013). We aimed at quantifying random errors by analysing existing data and the processes involved, while eliminating systematic errors through the processes of homogenisation.

\subsubsection{Glaciological balances}

The uncertainties in glaciological balance were quantified from an analysis of the following factors.

1. Uncertainty of point measurements ( $\sigma$.glac.point) due to uncertainty in

- probing to the summer surface (probe may penetrate the summer surface layer or stop at layers above the summer surface, recording or reading may be incorrect),

- stakes and towers (stakes may fall down or melt out, towers may be anchored to firn/ice masses at lower depths and thus be vertically displaced),

- density measurements of snow (measurement or recording errors, errors or unrepresentative depthdensity conversion formula), and

- density of firn (normally not measured, but estimated).

2. Uncertainty of spatial integration ( $\sigma$.glac.spatial) considering

- number of stakes for each (50) $100 \mathrm{~m}$ vertical band used for calculating balances,

- number of probings for each (50) $100 \mathrm{~m}$ vertical bands used for calculating balances, and 
- effect of areas not covered by stakes or probings due to ice falls and crevasses.

3. Uncertainty of glacier reference area ( $\sigma$.glac.ref) due to

- glacier area-altitude changes and

- problems in determining the ice divide.

As most of the factors in the glaciological error budget could not be quantified from independent measurements, an expert opinion approach was taken. The glaciologist in charge of the measurements quantified the error in collaboration with a glaciologist with modest involvement in the measurements.

\subsubsection{Geodetic balances}

The uncertainties of geodetic balance were quantified from an analysis of the following factors.

1. Uncertainty due to digital terrain models ( $\sigma$.geod.DTM) compared to reference DTM (high-accuracy laser), ground control points, surveyed points on the ice surface, if available, and type of data acquisition (laser, high-quality photo, low-quality photo).

2. Uncertainty due to density conversion $(\sigma . \mathrm{dc})$ using the density conversion factor as described in Sect. 3.3.

3. Uncertainty of Internal balance ( $\sigma$.int) was not subject to any detailed uncertainty analysis due to lack of independent data, but as it is only an estimate we assume an uncertainty of $\pm 33 \%$.

\subsubsection{Example: uncertainty of the Nigardsbreen records}

The uncertainty in the Nigardsbreen glaciological mass balance totalled $\pm 0.33 \mathrm{~m}$ w.e. $\mathrm{a}^{-1}$ (no differentiation was possible between the two periods 1964-1984 and 1984-2013). This uncertainty has three components:

1. point measurement uncertainty was \pm 0.25 based on $\pm 0.15 \mathrm{~m}$ w.e. $\mathrm{a}^{-1}$ from identifying the summer surface, \pm 0.20 from stakes and towers, \pm 0.05 from snow density, and $\pm 0.02 \mathrm{~m}$ w.e. $\mathrm{a}^{-1}$ from firn density;

2. spatial interpolation uncertainty was \pm 0.21 , based on $\pm 0.15 \mathrm{~m}$ w.e. $\mathrm{a}^{-1}$ from vertical range and coverage, \pm 0.10 from coverage, and $\pm 0.10 \mathrm{~m}$ w.e. $\mathrm{a}^{-1}$ from lack of coverage in ice falls and crevassed areas; and

3. glacier reference area uncertainty was \pm 0.06 , based on $\pm 0.04 \mathrm{~m}$ w.e. $\mathrm{a}^{-1}$ from ice divide and $\pm 0.05 \mathrm{~m}$ w.e. $\mathrm{a}^{-1}$ from DTMs.

The uncertainty in the geodetic mass balance totalled \pm 0.16 for 1964-1984 and $\pm 0.08 \mathrm{~m}$ w.e. $\mathrm{a}^{-1}$ for 1984-2013. For the first period, the uncertainty in DTMs was 0.16 and density conversion was $0.08 \mathrm{~m}$ w.e. $\mathrm{a}^{-1}$. For the second period, the

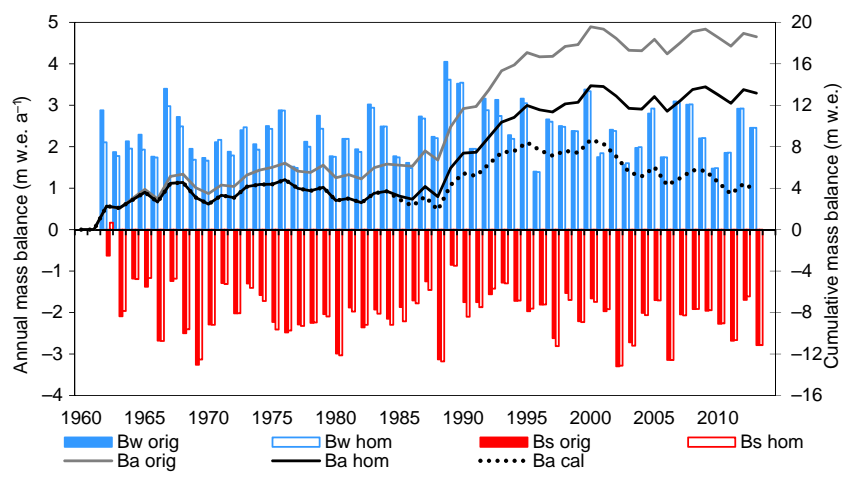

Figure 5. Original, homogenised, and calibrated mass-balance series for Nigardsbreen. Annual values are shown for $B_{\mathrm{w}}$ and $B_{\mathrm{s}}$ and cumulative values are shown for $B_{\mathrm{a}}$. See Table $\mathrm{S} 1$ for individual values.

uncertainty in DTMs was 0.08 and density conversion was $0.01 \mathrm{~mm}$ w.e. $\mathrm{a}^{-1}$. The uncertainty in internal ablation was estimated to $0.06 \mathrm{~m}$ w.e. $\mathrm{a}^{-1}$.

\section{Results}

\subsection{Homogenised balances}

The detailed homogenisation of the glaciological mass balances resulted in changes in seasonal, annual, and cumulative values.

For Nigardsbreen, the homogenised mass-balance series over the period 1962-2013 showed a positive mass balance of $13.2 \mathrm{~m}$ w.e., which is $5.4 \mathrm{~m}$ w.e. less than the cumulative balance of the original series for the same period (Fig. 5, Table S1). The cumulative winter balance was reduced by $4.6 \mathrm{~m}$ w.e. ( $84 \%$ of the total decrease), while the change in cumulative summer balance was $-0.9 \mathrm{~m}$ w.e. $(16 \%)$. Generally, the homogenised mass-balance series over the period 1962-2013 gave a lower mean winter balance than the original series, while the mean summer balances were both lower and higher than the original values. The mean winter balance decrease was $0.09 \mathrm{~m}$ w.e. $\mathrm{a}^{-1}$, and the mean summer balance change was $-0.02 \mathrm{~m}$ w.e. $\mathrm{a}^{-1}$. The impact of the five major changes in methodology was difficult to quantify individually, as it was a joint process homogenising the year-by-year data and from this recalculating the mass balance. The homogenisation of ice divide, basin, and change of method from contour to profile area-altitude distribution gave small differences if isolated for one change only, typically within $\pm 0.1 \mathrm{~m}$ w.e. The greatest contribution to the cumulative mass-balance reduction of $5.4 \mathrm{~m}$ w.e. for Nigardsbreen was ascribed to the individual errors detected in the revisit of the data and the calculations.

For Ålfotbreen, the homogenised mass-balance series over the period 1963-2010 showed a positive mass balance of $4.7 \mathrm{~m}$ w.e., a reduction of $1.6 \mathrm{~m}$ w.e. compared to the orig- 


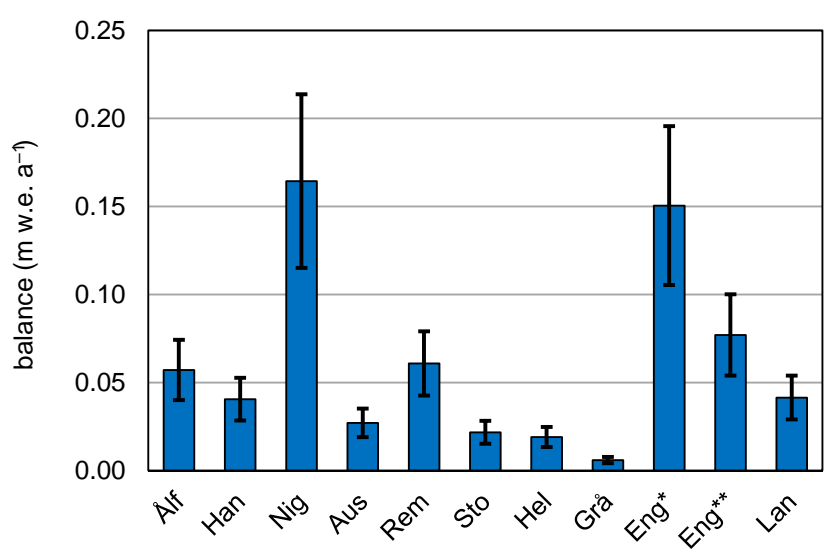

Figure 6. Calculated internal ablation for the 10 study glaciers. The values are the annual mean for the reference period 1989-2013. Calculations are divided in two periods for Engabreen, ${ }^{*} 1989-1992$ and **1993-2013, since the subglacial water was captured by a tunnel under the glacier from 1993. Error bars are one-third of the calculated value.

inal series for the same period. For Hansebreen over the period 1986-2010 the homogenised cumulative $B_{\mathrm{a}}$ was $-15.1 \mathrm{~m}$ w.e., a $1.4 \mathrm{~m}$ w.e. greater deficit than the original series. For Engabreen, the homogenisation resulted in a reduction of the cumulative $B_{\mathrm{a}}$ to $1.5 \mathrm{~m}$ w.e. For Hellstugubreen and Langfjordjøkelen, the cumulative mass balance was 1.3 and $1.0 \mathrm{~m}$ w.e. less negative respectively; these changes are mainly attributed to the recalculation of the mass balance using the newer DTMs and homogenous ice divides for the two glaciers. At Austdalsbreen, the mean contribution of calving to the annual balance increased from 0.26 to $0.30 \mathrm{~m}$ w.e. $\mathrm{a}^{-1}$. Thus, calving represents $11 \%$ of the summer balance in the period of measurements (1988-2014). The homogenised cumulative $B_{\mathrm{a}}$ for $1988-2009$ is more negative $(-9.8 \mathrm{~m}$ w.e.) than the original values ( $-6.4 \mathrm{~m}$ w.e.). For the other glaciers there were only minor changes in the cumulative $B_{\mathrm{a}}$ resulting from the homogenisation.

\subsection{Internal balance}

Results of the internal ablation calculations show that the mean contribution over the period 1989-2014 varies from glacier to glacier (Fig. 7). The highest values are for Nigardsbreen and Engabreen: -0.16 and $-0.15 \mathrm{~m}$ w.e. $\mathrm{a}^{-1}$ respectively. This is due to high precipitation combined with a large elevation range. All other glaciers have small internal ablation rates of $0.01-0.06 \mathrm{~m}$ w.e. $\mathrm{a}^{-1}$, mainly due to small elevation differences or small precipitation volumes. All values were calculated for a common period (1989-2014) to compare the absolute contribution between the glaciers. For Engabreen the period was divided into two: before and after the subglacial water intakes constructed in 1993, when much of the sub-glacial run-off was captured by the hydropower diversion tunnel. As a result, according to the cal-

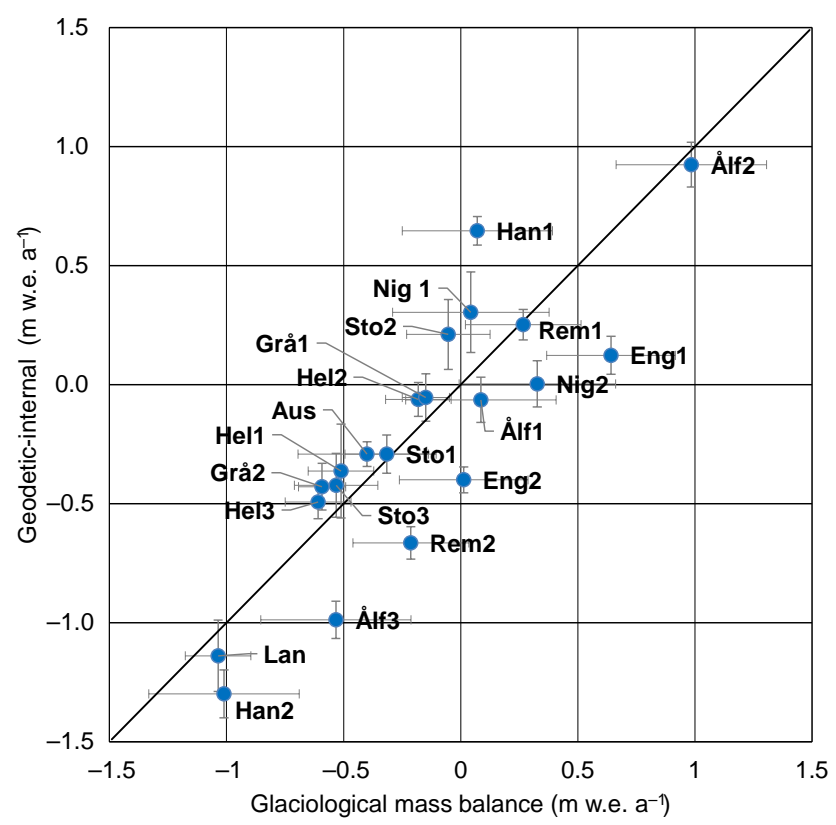

Figure 7. Glaciological vs. geodetic mass balance, subtracting the calculated internal mass balance from the geodetic balance, with error bars for glaciological and geodetic. Glacier names are shown with three characters as in Fig. 1. Numbers are added for glaciers with multiple geodetic periods; e.g. Eng1 refers to the first geodetic period and Eng2 to the second period for Engabreen.

culations, the annual contribution from internal ablation decreased from 0.15 to $0.08 \mathrm{~m}$ w.e. $\mathrm{a}^{-1}$. The contribution of internal and basal melt varies from year to year due to varying meteorological conditions. For example, for Nigardsbreen, the average annual internal balance over 1989-2013 was calculated to be $-0.16 \pm 0.04 \mathrm{~m}$ w.e. $\mathrm{a}^{-1}$. Values for individual years over the period 1962-2014 ranged from -0.09 to $-0.24 \mathrm{~m}$ w.e. $\mathrm{a}^{-1}$. The mean homogenised surface summer balance was $-2.05 \mathrm{~m}$ w.e. over the period $1962-2014$, so this contribution represents an $8 \pm 3 \%$ additional melt from what is measured at the surface. Internal ablation is a significant contribution for the long-term series of Nigardsbreen, amounting to $-8.5 \pm 2.1 \mathrm{~m}$ w.e. for the 53 years of measurements over 1962-2014.

\subsection{Uncertainty and comparison}

The results from the uncertainty analysis (Table 4) show that largest uncertainties were associated with point measurements on maritime glaciers (above $0.20-0.25 \mathrm{~m}$ w.e. $\mathrm{a}^{-1}$ ), followed by spatial integration at glaciers with few stakes per elevation band (about $0.15-0.21 \mathrm{~m}^{\text {w.e. }} \mathrm{a}^{-1}$ ). The largest point errors were on glaciers with a large mass turnover and with challenging probing conditions due to deep snow packs and more uncertain summer surfaces, in particular in years with much snow remaining from the previous year, and difficulties in maintaining the stake network, both in summer 
and winter season. The largest spatial interpolation errors were typically at the outlet glaciers with a large accumulation plateau draining ice down through a heavily crevassed icefall leading to the snout - making it difficult to measure at all elevations and parts of the glacier. At Nigardsbreen, Engabreen and Rembesdalskåka only 1-2 stakes are available below the main plateau (see Fig. 3 for Nigardsbreen), However, this part covers less than $10 \%$ of the total area; see also Kjøllmoen (2016a) and Elvehøy (2016) for further details. Other glaciers and error components were small, in the range $0.01-0.12 \mathrm{~m}$ w.e. $\mathrm{a}^{-1}$. Uncertainties in geodetic mass balances were largest where old maps were used (up to $0.23 \mathrm{mw}$ e. $\mathrm{a}^{-1}$ ), but most were in the range $0.05-$ $0.10 \mathrm{~m}$ w.e. $\mathrm{a}^{-1}$. The error in density corrections was small $\left(0.05 \mathrm{~m}\right.$ w.e. $\left.\mathrm{a}^{-1}\right)$. The uncertainty in internal balance was assumed to be one-third of the balance: above $0.06 \mathrm{~m}$ w.e. $\mathrm{a}^{-1}$ for three maritime glaciers and very small for the others.

Glaciological and geodetic balances were compared for 21 periods (Table 4, Fig. 8). In this comparison, the internal balance was taken into account by subtracting it from the geodetic balance. The discrepancies and tests of the hypothesis are shown in Table 5. Good agreement (less than $0.20 \mathrm{mw}$ e. $\mathrm{a}^{-1}$ ) was found for 12 periods, whilst 5 periods showed discrepancies above $0.40 \mathrm{mw}^{-e} \mathrm{a}^{-1}$. The four remaining periods had discrepancies between 0.26 and $0.32 \mathrm{mw}$.e. $\mathrm{a}^{-1}$. The data from the maritime glaciers (Engabreen, Nigardsbreen, Ålfotbreen, Hansebreen) deviated the most, in addition to one period for Rembesdalskåka and Storbreen. The glaciological mass balance was more positive than the geodetic for most large deviations, except for the first period of Hansebreen.

Uncertainty was included in the comparison in order to test the null hypothesis (H0: "the cumulative glaciological balance is not statistically different from the geodetic balance") and to check whether unexplained discrepancies suggest calibration be applied (Zemp et al., 2013). Testing at the $95 \%$ acceptance level showed that the null hypothesis was rejected for seven periods: Alfotbreen (1997-2010), Hansebreen (1988-1997 and 1997-2010), Nigardsbreen (1984-2013), and Engabreen (1969-2001, 2001-2008). Another two periods, Nigardsbreen (1964-1984) and Storbreen (1984-1997), gave deviations above $0.2 \mathrm{~m}$ w.e. $\mathrm{a}^{-1}$, but due to the degree of uncertainty, $\mathrm{H} 0$ was not rejected. For the 12 other periods, deviations were smaller than $0.20 \mathrm{mw}^{\mathrm{e}} . \mathrm{a}^{-1}$ and within the uncertainties at the $95 \%$ acceptance level.

\subsection{Calibration}

Correcting the glaciological mass-balance series with geodetic observations is recommended where large, relative to the uncertainties, deviations are detected between glaciological and geodetic balances (Zemp et al., 2013). The deviations found between glaciological and geodetic surveys for several glaciers in our study calls for a calibration for 7 of the 21 periods. Previous studies have suggested using sta-
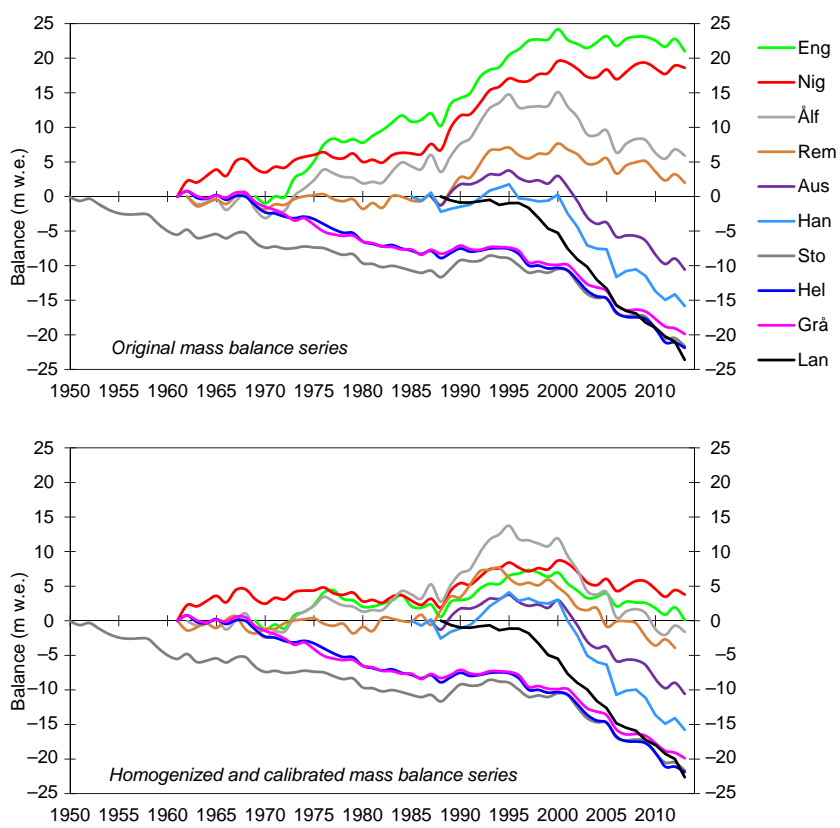

Figure 8. Cumulative glaciological mass balances for the 10 longterm glaciers. Upper diagram shows original series prior to homogenisation. Lower diagram shows homogenised and partly calibrated series. Calibration was applied to Nigardsbreen (19842013), Hansebreen (1988-2010), Ålfotbreen (1997-2010), Rembesdalskåka (1995-2010), and Engabreen (1970-2008).

tistical variance analysis (Thibert and Vincent, 2009), distributed mass-balance modelling (Huss et al., 2009), or by distributing equally the mean annual difference between the homogenised glaciological and geodetic balance (Zemp et al., 2013). In the latter case, the difference in the annual balance $B_{\mathrm{a}}$ is suggested to be fully assigned to the summer balance $B_{\mathrm{S}}$ (Zemp et al., 2013). To calibrate our data series, we used a slightly different approach. The annual correction is the annual difference between the homogenised geodetic and glaciological mass balance, $\Delta$, for each period (Table 5). This annual correction factor was applied to the summer and winter balances according to their relative size. In other words, when summer and winter balances were equal, $50 \%$ of the correction was applied to the summer balance and $50 \%$ to the winter balance. When the absolute summer balance was twice the winter balance, $2 / 3$ of the correction was applied to the summer balance and $1 / 3$ to the winter balance. The reasoning behind this was that the size of the error was probably related to the size of the balance. In years with a thick snow layer, the probing to the summer surface and maintenance of the stake network was more uncertain. In years with large melt, maintenance of stake networks was more difficult and the results less accurate. 
Table 4. Results of the mass balances and the uncertainty analysis for the 10 glaciers and 21 periods studied. Glacier names are shown with three characters as in Fig. 1. Numbers are added for glaciers with multiple geodetic periods. B is (glaciological, geodetic, and internal) mass balance and $\sigma$ is the estimated random error $( \pm)$ for the three balances. See Sect. 3.4.1. for explanation of terms. All mass balances and errors are in $\mathrm{m}$ w.e. $\mathrm{a}^{-1}$.

\begin{tabular}{|c|c|c|c|c|c|c|c|c|c|c|c|c|}
\hline No. & $\begin{array}{l}\text { Glacier } \\
\text { abrev. }\end{array}$ & Period & Years & B.glac & $\begin{array}{r}\sigma . \text { glac. } \\
\text { point }\end{array}$ & $\begin{array}{c}\sigma . \text { glac. } \\
\text { spatial }\end{array}$ & $\begin{array}{r}\sigma . \text { glac. } \\
\text { ref }\end{array}$ & B. geod & $\begin{array}{r}\sigma . g e o d . \\
\text { DTM }\end{array}$ & $\begin{array}{r}\sigma . \text { geod. } \\
\mathrm{dc}\end{array}$ & B.int & $\sigma$. int \\
\hline 1 & Ålf1 & 1968-1988 & 20 & 0.09 & 0.26 & 0.19 & 0.05 & -0.12 & 0.09 & 0.01 & -0.06 & 0.02 \\
\hline 1 & Ålf2 & 1988-1997 & 9 & 0.99 & 0.26 & 0.19 & 0.05 & 0.87 & 0.08 & 0.05 & -0.06 & 0.02 \\
\hline 1 & Ålf3 & $1997-2010$ & 13 & -0.53 & 0.26 & 0.19 & 0.05 & -1.05 & 0.04 & 0.06 & -0.06 & 0.02 \\
\hline 2 & Han1 & 1988-1997 & 9 & 0.07 & 0.26 & 0.19 & 0.05 & 0.61 & 0.05 & 0.04 & -0.04 & 0.01 \\
\hline 2 & Han2 & $1997-2010$ & 13 & -1.01 & 0.26 & 0.19 & 0.05 & -1.34 & 0.06 & 0.08 & -0.04 & 0.01 \\
\hline 3 & Nig1 & 1964-1984 & 20 & 0.04 & 0.26 & 0.21 & 0.06 & 0.14 & 0.16 & 0.01 & -0.16 & 0.05 \\
\hline 3 & Nig2 & 1984-2013 & 29 & 0.33 & 0.26 & 0.21 & 0.06 & -0.16 & 0.08 & 0.01 & -0.16 & 0.05 \\
\hline 4 & Aus & 1988-2009 & 21 & -0.40 & 0.21 & 0.20 & 0.06 & -0.32 & 0.05 & 0.02 & -0.03 & 0.01 \\
\hline 5 & Rem1* & $1962-1995$ & 33 & 0.27 & 0.12 & 0.21 & 0.06 & 0.19 & 0.06 & 0.01 & -0.06 & 0.02 \\
\hline 5 & Rem2 & 1995-2010 & 15 & -0.21 & 0.12 & 0.21 & 0.06 & -0.73 & 0.05 & 0.04 & -0.06 & 0.02 \\
\hline 6 & Sto1 & 1968-1984 & 16 & -0.32 & 0.08 & 0.16 & 0.01 & -0.31 & 0.08 & 0.02 & -0.02 & 0.01 \\
\hline 6 & Sto2 & 1984-1997 & 13 & -0.05 & 0.08 & 0.16 & 0.01 & 0.19 & 0.15 & 0.01 & -0.02 & 0.01 \\
\hline 6 & Sto3 & 1997-2009 & 12 & -0.53 & 0.08 & 0.16 & 0.01 & -0.45 & 0.13 & 0.03 & -0.02 & 0.01 \\
\hline 7 & Hel1 & 1968-1980 & 12 & -0.51 & 0.08 & 0.12 & 0.01 & -0.38 & 0.20 & 0.02 & -0.02 & 0.01 \\
\hline 7 & $\mathrm{Hel} 2$ & 1980-1997 & 17 & -0.18 & 0.08 & 0.12 & 0.01 & -0.08 & 0.07 & 0.01 & -0.02 & 0.01 \\
\hline 7 & Hel3 & 1997-2009 & 12 & -0.61 & 0.08 & 0.12 & 0.01 & -0.51 & 0.06 & 0.03 & -0.02 & 0.01 \\
\hline 8 & Grå1 & 1984-1997 & 13 & -0.15 & 0.07 & 0.07 & 0.01 & -0.06 & 0.10 & 0.00 & -0.01 & 0.00 \\
\hline 8 & Grå2 & $1997-2009$ & 12 & -0.59 & 0.07 & 0.07 & 0.01 & -0.44 & 0.09 & 0.03 & -0.01 & 0.00 \\
\hline 9 & Eng1* & 1969-2001 & 32 & 0.64 & 0.20 & 0.19 & 0.01 & -0.03 & 0.06 & 0.00 & -0.15 & 0.05 \\
\hline 9 & Eng2 & 2001-2008 & 7 & 0.01 & 0.20 & 0.19 & 0.01 & -0.48 & 0.04 & 0.03 & -0.08 & 0.03 \\
\hline 10 & Lan & 1994-2008 & 14 & -1.04 & 0.08 & 0.12 & 0.01 & -1.18 & 0.13 & 0.07 & -0.04 & 0.01 \\
\hline
\end{tabular}

* For Eng1 and Rem1 the geodetic survey is 1 year before the first year of glaciological mass balance; the comparison period was adjusted to fit the glaciological measurement period.

\subsection{Reanalysed glaciological series}

The reanalysed glaciological series, resulting from homogenisation and calibration, reduced the positive cumulative balances measured at some of the Norwegian glaciers. The major changes in cumulative balances up to and including year 2013 are (the part of reduction due to calibration in parenthesis)

1. Engabreen reduced by 20.5 (19.5) $\mathrm{m}$ w.e. since 1970

2. Nigardsbreen reduced by 14.8 (9.4) m w.e. since 1962

3. Ålfotbreen reduced by 7.5 (5.9) $\mathrm{m}$ w.e since 1963

4. Rembesdalskåka reduced by 5.9 (6.8) m w.e. since 1963

5. Austdalsbreen reduced by $3.6 \mathrm{~m}$ w.e. since 1988 .

For Rembesdalskåka the homogenisation resulted in more positive balance; thus the calibrated part is larger than the total reduction. Austdalsbreen was not calibrated; the reduction is only due to the homogenisation. The other glaciers had small or no change (within $\pm 1.3 \mathrm{~m}$ w.e.). The reanalysed series show a much more consistent signal then the original data (Fig. 8.). The previously reported difference of the cumulative balances of the maritime and continental glaciers is still present but much less pronounced. Six glaciers have a large mass loss (cumulative balance between -14 and $-22 \mathrm{~m}$ w.e.) and four glaciers are nearly in balance (cumulative balance within $\pm 4 \mathrm{~m}$ w.e.). Original data showed a marked surplus for three glaciers (up to $21 \mathrm{~m}$ w.e.). A period of surplus is still visible in the data, but now mainly as a transient surplus for the period 1989-1995. The cumulative results further highlight the marked loss of mass during the period after 2000 for all glaciers.

\section{Discussion}

\subsection{Calibration}

The resulting cumulative curves after the homogenisation and calibration showed that the distinctly positive cumulative mass balances measured at Engabreen and Nigardsbreen were much reduced. When calibrating we accounted for the internal balance by subtracting it from the geodetic mass balance before comparing it with the glaciological. This was done to ensure that the glaciological balance was still the surface mass balance, which is what we measure for all glaciers. The degree of calibration thus also depends on how much in- 
Table 5. Comparison of glaciological and geodetic mass balances. $\Delta$ (in $\mathrm{m}$ w.e. $\mathrm{a}^{-1}$ ) is the difference over the period of record between cumulative glaciological balance and geodetic balance, corrected for internal ablation. $\delta$ (dimensionless) is the reduced discrepancy, where uncertainties are accounted for. $\beta$ is the probability of accepting $\mathrm{H} 0$ although the results of the two methods are different at the $95 \%$ confidence level, while $\varepsilon$ (in m w.e. $\mathrm{a}^{-1}$ ) is the limit for detection of bias. Bold is used to highlight periods with less than 10 years length, differences larger than $0.20 \mathrm{~m}$ w.e. $\mathrm{a}^{-1}$, and reduced discrepancies larger than 1.96 .

\begin{tabular}{llrrrrrr}
\hline No. & Glacier & Period & $\Delta$ & $\delta$ & H0 & $\beta$ & $\varepsilon$ \\
\hline 1 & Ålf1 & $1968-1988$ & 0.15 & 1.26 & yes & 76 & 0.43 \\
1 & Ålf2 & $1988-1997$ & 0.06 & 0.43 & yes & 93 & 0.51 \\
1 & Ålf3 & $1997-2010$ & 0.46 & 3.84 & no & 3 & 0.43 \\
2 & Han1 & $1988-1997$ & -0.58 & -4.69 & no & 0 & 0.44 \\
2 & Han2 & $1997-2010$ & 0.29 & 2.14 & no & 43 & 0.49 \\
3 & Nig1 & $1964-1984$ & -0.26 & -1.41 & yes & 71 & 0.67 \\
3 & Nig2 & $1984-2013$ & 0.32 & 2.81 & no & 20 & 0.42 \\
4 & Aus & $1988-2009$ & -0.11 & -1.30 & yes & 74 & 0.3 \\
5 & Rem1 & $1961-1995$ & 0.02 & 0.27 & yes & 94 & 0.28 \\
5 & Rem2 & $1995-2010$ & 0.45 & 4.85 & no & 0 & 0.34 \\
6 & Sto1 & $1968-1984$ & -0.02 & -0.26 & yes & 94 & 0.33 \\
6 & Sto2 & $1984-1997$ & -0.26 & -1.70 & yes & 60 & 0.56 \\
6 & Sto3 & $1997-2009$ & -0.11 & -0.76 & yes & 88 & 0.52 \\
7 & Hel1 & $1968-1980$ & -0.15 & -0.74 & yes & 89 & 0.73 \\
7 & Hel2 & $1980-1997$ & -0.12 & -1.51 & yes & 67 & 0.28 \\
7 & Hel3 & $1997-2009$ & -0.12 & -1.44 & yes & 70 & 0.29 \\
8 & Grå1 & $1984-1997$ & -0.10 & -0.91 & yes & 85 & 0.37 \\
8 & Grå2 & $1997-2009$ & -0.16 & -1.59 & yes & 64 & 0.37 \\
9 & Eng1 & $1969-2001$ & 0.52 & 5.54 & no & 0 & 0.34 \\
9 & Eng2 & $2001-2008$ & 0.41 & 3.53 & no & 6 & 0.42 \\
10 & Lan & $1994-2008$ & 0.10 & 0.67 & yes & 90 & 0.56 \\
\hline
\end{tabular}

ternal melt we estimate. The internal ablation rates calculated for the two maritime glaciers, Engabreen and Nigardsbreen, with a large elevation range was significant and represented a marked difference between the glaciological and geodetic methods. For the 49 years compared for Nigardsbreen, internal ablation amounted to nearly $-8 \mathrm{~m}$ w.e. according to our calculations. Oerlemans (2013) estimated an even higher dissipative melt of $-0.23 \mathrm{~m}$ w.e. $\mathrm{a}^{-1}$ for Nigardsbreen. Using this value would give more than $-11 \mathrm{~m}$ w.e. resulting from the internal balance over the 49 years. Although both values must be considered only an estimate, it demonstrates how sensitive cumulative series are both to systematic biases and to generic differences between the methods. For Engabreen, almost all the change in cumulative values is due to the calibration of the two geodetic periods and the amount of internal ablation controls the amount of calibration. A higher estimate of internal ablation for this glacier would lead to a smaller difference between the methods and thus less reduction in the mass surplus of the glaciological series. Thus, due care must be shown when interpreting cumulative curves, in particular for glaciers located in high-precipitation regions spanning a large elevation range, such as Engabreen and $\mathrm{Ni}$ gardsbreen.

\subsection{Implications and outlook}

The reanalysis processes has altered seasonal, annual, and cumulative as well as ELA and AAR values for many of the years for the 10 glaciers presented here. For most glaciers the discrepancy between the "original" glaciological series as published in the series "Glaciological investigations in Norway" (e.g. Kjøllmoen et al., 2011) are small, but for others results differed significantly. We plan to keep the series "original", "homogenised", and "calibrated" in the NVE databases and flag them accordingly as proposed by Zemp et al. (2013) and as exemplified for Nigardsbreen (Table S1). The new reanalysed and thus "official" values will also be made available for download from NVE's website www.nve.no/glacier and submitted to WGMS with a remark on the reanalysis status.

The level of analysis in the homogenising process varied between the 10 study glaciers, according to the volume and quality of detailed data and metadata. For some of the glaciers (Nigardsbreen, Engabreen, Alfotbreen, and Hansebreen) a detailed homogenisation process was carried out, going through the data material for each year to search for inhomogeneities and possible biases in the data calculations. This should also be considered applied to the other six glaciers, as well as on other glaciers not included here that have shorter series. However, for some glaciers, e.g. Rembesdalskåka and Storbreen, the point data and metadata used for the calculations are simply not available for many of the early years, and a detailed scrutinising of the data and recalculation is not possible.

The glaciers that show good agreement between glaciological and geodetic measurements (Austdalsbreen, Storbreen, Hellstugubreen, Gråsubreen, Langfjordjøkelen) have several things in common. Their size is small to medium (2.2$\left.10.6 \mathrm{~km}^{2}\right)$, and they have a higher stake density $\left(1-6 \mathrm{~km}^{-2}\right)$ than Nigardsbreen and Engabreen $\left(0.2 \mathrm{~km}^{2}\right)$. Furthermore, most parts are accessible, providing a better stake coverage with altitude. Their altitudinal range is lower and their areaaltitude distribution is uniform and not dominated by a flat upper part as in Nigardsbreen and Engabreen. Their glacier basins are also more defined. Furthermore, except for Austdalsbreen, the glaciers had a considerable mass loss and have more or less been constantly loosing mass throughout the observation record. Thus, smaller mountain glaciers with negative cumulative balances seems to be easier to measure correctly than the maritime outlet glaciers.

As mentioned, on many of the glaciers a change of the observation programme was made after statistical analysis of the previous years' accumulation and ablation patterns in the 1980s. This was done to reduce the amount of fieldwork and hence reduce costs and personnel resources. Studies have pointed out that there can be a good correlation between one stake and the glacier-wide averages (Roald, 1973; Rasmussen and Andreassen, 2005). 
Glaciological mass-balance programmes, based on a minimal network of long-term ablation and accumulation point measurements, are recommended to increase the observational network once every decade in order to reassess the spatial pattern of mass balance (Zemp et al., 2013). The present results may call for a temporarily increased observational network on the glaciers with the largest differences between the methods (Engabreen, Nigardsbreen, Ålfotbreen, Hansebreen and Rembesdalskåka) to adjust the observational programmes in order to reduce uncertainty. It should be emphasized that it is far more challenging and expensive to maintain a stake network on a large glacier with high mass turnover like Nigardsbreen, where parts of the glacier must be visited by helicopter and stakes need maintenance several times a year, than on the small Gråsubreen where stakes may survive many years and all parts are accessible by foot. However, although smaller glaciers seems to be easier to measure correctly, the maritime outlet glaciers represent by far the largest glacier area and ice volume (Andreassen et al., $2012 b, 2015)$. Continued geodetic surveys every 10 years are needed to measure the overall changes and provide data for new reanalysis. The resent geodetic surveys by airborne laser scanning conducted over the period 2008-2013 covered not only the 10 mass-balance glaciers presented here but also about one-third of the glacial area in Norway. The surveys provide an accurate baseline for future repeated mapping and glacier change detection. They will also be used for a regional overview of glacier volume changes from the $1960 \mathrm{~s}$ to 2010 s.

\section{Conclusions}

This study provided homogenised data series of glaciological and geodetic mass balance for the 10 glaciers in Norway with long-term observations. In total, 21 periods of data were compared. Uncertainties were quantified for relevant sources of errors, both in the glaciological and geodetic series.

Glaciological and geodetic results were in overall agreement for Langfjordjøkelen, Austdalsbreen, Storbreen, Hellstugubreen, and Gråsubreen for the periods considered, but they differed for Alfotbreen (one of three periods), Hansebreen (both periods), Engabreen (both periods), Rembesdalskåka (one of two periods), and Nigardsbreen (one of two periods). Whereas the homogenised glaciological surface mass balance for these glaciers shows a clear cumulative mass surplus over the period of records, the geodetic observations show glaciers in near balance or with a deficit. The glaciological method measures the surface mass balance, while the geodetic method measures surface, internal, and basal mass balances. The contribution from internal and basal mass balances was calculated and revealed values $>0.1 \mathrm{mw}^{\mathrm{e}}$. $\mathrm{a}^{-1}$ for Nigardsbreen and Engabreen. Internal and basal melting may therefore represent a significant contribution to the mass bal- ance for long-term series, in particular for glaciers in a wet climate with wide elevation range.

Although part of the discrepancy between the glaciological and geodetic methods could be explained by homogenisation and by the estimated contribution from internal and basal melt, the discrepancy is large for several periods. For 9 of the 21 periods compared the unexplained discrepancy between the methods amounts to $>0.20 \mathrm{~m}$ w.e. $\mathrm{a}^{-1}$. The reanalysis re-

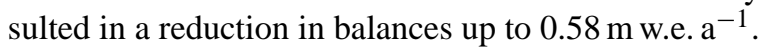

The reanalysed series shows a more spatially coherent signal over the period of measurements than previously reported: six glaciers have a significant mass loss and four glaciers are nearly in balance. All glaciers have lost mass after year 2000. The reanalysis effort has therefore contributed towards a better understanding of Norwegian glacier massbalance changes since the 1960s.

\section{The Supplement related to this article is available online at doi:10.5194/tc-10-535-2016-supplement.}

Acknowledgements. The authors thank M. Zemp, World Glacier Monitoring Service, for valuable support and discussions during the work with this paper. We thank J. Oerlemans for providing advice on the calculation of internal ablation. We also thank A. Kääb, C. Nuth, and M. Huss for valuable discussions. We thank Tomas Johannesson, Mauri Pelto, an anonymous referee, and the scientific editor Etienne Berthier for valuable comments to our manuscript in The Cryosphere Discussions. John Brittain is thanked for proofreading the paper. We thank Statkraft AS for providing support to the laser-scanning campaigns. The laser scannings were also supported through the project "Mapping the Surface and surface changes of glaciers and ice caps in Norway, Iceland and Greenland with LiDAR", funded by Nordisk Ministerråd. This publication is contribution number 78 of the Nordic Centre of Excellence SVALI, "Stability and Variations of Arctic Land Ice", funded by the Nordic Top-level Research Initiative (TRI).

Edited by: E. Berthier

\section{References}

Alexander, D., Shulmeister, J., and Davies, T.: High basal melting rates within high-precipitation temperate glaciers, J. Glaciol., 57, 789-795, 2011.

Alexander, D., Davies, T., and Schulmeister, J.: Basal melting beneath a fast-flowing temperate tidewater glacier, Ann. Glaciol., 54, 265-271, doi:10.3189/2013AoG63A259, 2013.

Andreassen, L. M.: Comparing traditional mass balance measurements with long-term volume change extracted from topographical maps: a case study of Storbreen glacier in Jotunheimen, Norway, for the period 1940-1997, Geogr. Ann. A, 81, 467-476, 1999. 
Andreassen, L. M., Elvehøy, H., Kjøllmoen, B., Engeset, R. V., and Haakensen, N.: Glacier mass-balance and length variation in Norway, Ann. Glaciol., 42, 317-325, 2005.

Andreassen, L. M., Kjøllmoen, B., Rasmussen, A., Melvold, K., and Nordli, Ø.: Langfjordjøkelen, a rapidly shrinking glacier in northern Norway, J. Glaciol., 58, 581-593, doi:10.3189/2012JoG11J014, 2012a.

Andreassen, L. M., Winsvold, S. H., Paul, F., and Hausberg, J. E.: Inventory of Norwegian Glaciers, NVE Rapport 38, Norwegian Water Resources and Energy Directorate, 2012b.

Andreassen, L. M., Huss, M., Melvold, K., Elvehøy, H., and Winsvold, S. H.: Ice thickness measurements and volume estimates for glaciers in Norway, J. Glaciol., 61, 763-775, doi:10.3189/2015JoG14J161, 2015.

Bader, H.: Sorge's law of densification of snow on high polar glaciers, J. Glaciol., 2, 319-323, 1954.

Cogley, J. G.: Geodetic and direct mass balance measurements: comparison and joint analysis, Ann. Glaciol., 50, 96-100, 2009.

Cogley, J. G., Hock, R., Rasmussen, L. A., Arendt, A. A., Bauder, A., Braithwaite, R. J., Jansson, P., Kaser, G., Möller, M., Nicholson, L., and Zemp, M.: Glossary of Glacier Mass Balance and Related Terms, IHP-VII Technical Documents in Hydrology No. 86, IACS Contribution No. 2, Paris, UNESCO-IHP, 114 pp., 2011.

Cuffey, K. M. and Paterson, W. S. B.: The Physics of Glaciers, 4. edn., Butterworth-Heinemann, Oxford, 704 pp., 2010.

Elvehøy, H.: Austdalsbreen, in: Glaciological investigations in Norway in 2010, edited by: Kjøllmoen, B., Andreassen, L. M., Elvehøy, H., Jackson, M., and Giesen, R. H., NVE Report 2, 2011.

Elvehøy, H.: Reanalysing of a mass balance record, Engabreen 1970-2014, NVE Rapport 29, Norwegian Water Resources and Energy Directorate, 2016.

Engelhardt, M., Schuler, T. V., and Andreassen, L.M. Glacier mass balance of Norway 1961-2010 calculated by a temperature-index model, Ann. Glaciol., 54, 32-40, doi:10.3189/2013AoG63A245, 2013

Escher-Vetter, H., Kuhn, M., and Weber, M.: Four decades of winter mass balance of Vernagtferner and Hintereisferner, Austria: methodology and results, Ann. Glaciol., 50, 87-95, 2009.

Fischer, A.: Glaciers and climate change: Interpretation of 50 years of direct mass balance of Hintereisferner, Global Planet. Change, 71, 13-26, 2010.

Fleig, A., Andreassen, L. M., Barfod, E., Haga, J., Haugen, L. E., Hisdal, H., Melvold, K., and Saloranta, T: Norwegian Hydrological Reference Dataset for Climate Change Studies, NVE Rapport 2, 2013

Funk, M. and Röthlisberger, H.: Forecasting the effect of a planned reservoir which will partially flood the tongue of Unteraargletcher in Switzerland, Ann. Glaciol., 13, 76-81, 1989.

Geist, T., Elvehøy, H., Jackson, M., and Stötter, J.: Investigations on intra-annual elevation changes using multitemporal airborne laser scanning data: Case study Engabreen, Norway, Ann. Glaciol., 42, 195-201, 2005.

Haug, T., Rolstad, C., Elvehøy, H., Jackson, M., and MaalenJohansen, I.: Geodetic mass balance of the western Svartisen ice cap, Norway, in the periods 1968-1985 and 1985-2002, Ann. Glaciol., 50, 119-125, 2009.
Holmlund, P., Jansson, P., and Pettersson, R.: A re-analysis of the 58 year mass balance record of Storglaciären, Sweden, Ann. Glaciol., 42, 389-394, 2005.

Huss, M.: Density assumptions for converting geodetic glacier volume change to mass change, The Cryosphere, 7, 877-887, doi:10.5194/tc-7-877-2013, 2013.

Huss, M., Dhulst, L., and Bauder, A.: New long-term massbalance series for the Swiss Alps, J. Glaciol., 61, 551-562, doi:10.3189/2015JoG15j015, 2015.

IPCC: Climate Change 2013: The Physical Science Basis, Contribution of Working Group I to the Fifth Assessment Report of the Intergovernmental Panel on Climate Change, edited by: Stocker, T. F., Qin, D., Plattner, G.-K., Tignor, M., Allen, S. K., Boschung, J., Nauels, A., Xia, Y., Bex, V., and Midgley, P. M., Cambridge University Press, Cambridge, United Kingdom and New York, NY, USA, 1535 pp., 2013.

Kääb, A.: Remote sensing of mountain glaciers and permafrost creep. Geographisches Institut der Universität Zürich, Zürich, 2005.

Kawamura, T., Fujii, Y., Satow, K., Kamiyama, K., Izumi, K., Kameda, T., Watanabe, O., Kawaguchi, S., Wold, B., and Gjessing, Y.: Glaciological characteristics of cores drilled on Jostedalsbreen, Southern Norway, Proceedings on the NIPR Symposium on Polar Meteorology and Glaciology No 2, 152 160, 1989.

Kjøllmoen, B.: Reanalysing a glacier mass balance measurement series - Nigardsbreen 1962-2013, NVE Rapport 30, Norwegian Water Resources and Energy Directorate, 2016a.

Kjøllmoen, B.: Reanalysing a glacier mass balance measurement series - Ålfotbreen (1963-2010) and Hansebreen (1986-2010), NVE Rapport 31, Norwegian Water Resources and Energy Directorate, $2016 \mathrm{~b}$.

Kjøllmoen, B., Andreassen, L. M., Elvehøy, H., Jackson, M., and Giesen, R. H.: Glaciological investigations in Norway in 2010, edited by: Kjøllmoen, B., NVE Report 2, Norwegian Water Resources and Energy Directorate, 2011.

Koblet, T., Gärtner-Roer, I., Zemp, M., Jansson, P., Thee, P., Haeberli, W., and Holmlund, P.: Reanalysis of multi-temporal aerial images of Storglaciären, Sweden (1959-99) - Part 1: Determination of length, area, and volume changes, The Cryosphere, 4, 333-343, doi:10.5194/tc-4-333-2010, 2010.

Laumann, T.: Snø, firn og is - en unders $\varnothing$ kelse på Hardangerjøkulen, Cand. real thesis, Dept. of Geography, University of Oslo, 40 pp., 1972.

Magnússon, E., Muñoz-Cobo Belart, J., Pálsson, F., Ágústsson, H., and Crochet, P.: Geodetic mass balance record with rigorous uncertainty estimates deduced from aerial photographs and lidar data - Case study from Drangajökull ice cap, NW Iceland, The Cryosphere, 10, 159-177, doi:10.5194/tc-10-159-2016, 2016.

Nesje, A. and Matthews, J. A.: The Briksdalsbre Event: A winter precipitation-induced decadal-scale glacial advance in southern Norway in the AD 1990s and its implications, Holocene, 22, 249-261, doi:10.1177/0959683611414938, 2012.

Nuth, C. and Kääb, A.: Co-registration and bias corrections of satellite elevation data sets for quantifying glacier thickness change, The Cryosphere, 5, 271-290, doi:10.5194/tc-5-271-2011, 2011.

Nuth, C., Moholdt, G., Kohler, J., Hagen, J. O., and Kääb, A. Svalbard glacier elevation changes and contribution to sea level 
rise, J. Geophys. Res., 115, F01008, doi:10.1029/2008JF001223, 2010.

Oerlemans, J.: A note on the water budget of temperate glaciers, The Cryosphere, 7, 1557-1564, doi:10.5194/tc-7-1557-2013, 2013.

Østrem, G. and Karlen, V.: Nigardsbreens hydrologi 1962, Norsk Geografisk Tidsskrift, 18, 156-202, doi:10.1080/00291956108551796, 1962.

Pelto, M., Kavanaugh, J., and McNeil, C.: Juneau Icefield Mass Balance Program 1946-2011, Earth Syst. Sci. Data, 5, 319-330, doi:10.5194/essd-5-319-2013, 2013.

Rasmussen, L. A.: Altitude variation of glacier mass balance in Scandinavia, Geophys. Res. Lett., 31, L13401, doi:10.1029/2004GL020273, 2004.

Rasmussen, L. A. and Andreassen, L. M.: Seasonal mass balance gradients in Norway, J. Glaciol., 51, 601-606, 2005.

Roald, L.: En undersøkelse over sambandet mellom nettobalansen malt på enkelte staker og breens totale nettobalanse, in: Glasiologiske undersøkelser i Norge 1971, edited by: Tvede, A. M., NVE rapport, 2, Norwegian Water Resources and Energy Directorate, 1973.

Rolstad, C., Haug, T., and Denby, B.: Spatially integrated geodetic glacier mass balance and its uncertainty based on geostatistical analysis: application to the western Svartisen ice cap, Norway, J. Glaciol., 55, 666-680, 2009.

Saloranta, T. M.: Simulating snow maps for Norway: description and statistical evaluation of the seNorge snow model, The Cryosphere, 6, 1323-1337, doi:10.5194/tc-6-1323-2012, 2012.

Saloranta, T. M.: New version (v.1.1.1) of the seNorge snow model and snow maps for Norway, Rapport 6-2014, Norwegian Water Resources and Energy Directorate, 30 pp., 2014.

Thibert, E. and Vincent, C.: Best possible estimation of mass balance combining glaciological and geodetic methods, Ann. Glaciol, 50, 112-118, 2009.

Thibert, E., Blanc, R., Vincent, C., and Eckert, N.: Glaciological and volumetric mass balance measurements error analysis over 51 years for the Sarennes glacier, French Alps, J. Glaciol., 54, 522-532, 2008.
Trachsel, M. and Nesje, A.: Modelling annual mass balances of eight Scandinavian glaciers using statistical models, The Cryosphere, 9, 1401-1414, doi:10.5194/tc-9-1401-2015, 2015.

WGMS: Glacier Mass Balance Bulletin No. 12 (2010-2011), in ICSU(WDS)/IUGG(IACS)/UNEP/UNESCO/WMO, World Glacier Monitoring Service, Zurich, Switzerland, edited by: Zemp, M., Nussbaumer, S. U., Naegeli, K., Gärtner-Roer, I., Paul, F., Hoelzle, M., and Haeberli, W., 106 pp., doi:10.5904/wgms-fog-2013-11, 2013.

Zemp, M., Jansson, P., Holmlund, P., Gärtner-Roer, I., Koblet, T., Thee, P., and Haeberli, W.: Reanalysis of multi-temporal aerial images of Storglaciären, Sweden (1959-99) - Part 2: Comparison of glaciological and volumetric mass balances, The Cryosphere, 4, 345-357, doi:10.5194/tc-4-345-2010, 2010.

Zemp, M., Thibert, E., Huss, M., Stumm, D., Rolstad Denby, C. Nuth, C., Nussbaumer, S. U., Moholdt, G., Mercer, A., Mayer, C., Joerg, P. C., Jansson, P., Hynek, B., Fischer, A., Escher-Vetter, H., Elvehøy, H., and Andreassen, L. M.: Reanalysing glacier mass balance measurement series, The Cryosphere, 7, 12271245, doi:10.5194/tc-7-1227-2013, 2013.

Zemp, M., Frey, H., Gärtner-Roer, I., Nussbaumer, S. U., Hoelzle, M., Paul, F., Haeberli, W., Denzinger, F., Ahlstrøm, A. P., Anderson, B., Bajracharya, S., Baroni, C., Braun, L. N., Cáceres, B. E., Casassa, G., Cobos, G., Dávila, L. R., Delgado Granados, H., Demuth, M. N., Espizua, L., Fischer, A., Fujita, K., Gadek, B., Ghazanfar, A., Hagen, J. O., Holmlund, P., Karimi, N., Li, Z., Pelto, M., Pitte, P., Popovnin, V. V., Portocarrero, C. A., Prinz, R., Sangewar, C. V., Severskiy, I., Sigurðsson, O., Soruco, A., Usubaliev, R., and Vincent, C.: Historically unprecedented global glacier decline in the early 21 st century, J. Glaciol., 61, 745-762, doi:10.3189/2015JoG15J017, 2015. 